\title{
Effect of vitamin E on glutathione-dependent enzymes
}

Citation for published version (APA):

van Haaften, R. I. M., Haenen, G. R. M. M., Evelo, C. T. A., \& Bast, A. (2003). Effect of vitamin E on glutathione-dependent enzymes. Drug Metabolism Reviews, 35(2-3), 215-253.

https://doi.org/10.1081/DMR-120024086

Document status and date:

Published: 01/01/2003

DOI:

10.1081/DMR-120024086

Document Version:

Publisher's PDF, also known as Version of record

Document license:

Taverne

\section{Please check the document version of this publication:}

- A submitted manuscript is the version of the article upon submission and before peer-review. There can be important differences between the submitted version and the official published version of record.

People interested in the research are advised to contact the author for the final version of the publication, or visit the DOI to the publisher's website.

- The final author version and the galley proof are versions of the publication after peer review.

- The final published version features the final layout of the paper including the volume, issue and page numbers.

Link to publication

\footnotetext{
General rights rights.

- You may freely distribute the URL identifying the publication in the public portal. please follow below link for the End User Agreement:

www.umlib.nl/taverne-license

Take down policy

If you believe that this document breaches copyright please contact us at:

repository@maastrichtuniversity.nl

providing details and we will investigate your claim.
}

Copyright and moral rights for the publications made accessible in the public portal are retained by the authors and/or other copyright owners and it is a condition of accessing publications that users recognise and abide by the legal requirements associated with these

- Users may download and print one copy of any publication from the public portal for the purpose of private study or research.

- You may not further distribute the material or use it for any profit-making activity or commercial gain

If the publication is distributed under the terms of Article $25 \mathrm{fa}$ of the Dutch Copyright Act, indicated by the "Taverne" license above, 
Drug Metabolism Reviews

\section{Effect of Vitamin E on Glutathione-Dependent Enzymes}

\section{Rachel I. M. van Haaften, Guido R. M. M. Haenen, Chris T. A. Evelo \& Aalt Bast}

To cite this article: Rachel I. M. van Haaften, Guido R. M. M. Haenen, Chris T. A. Evelo \& Aalt Bast (2003) Effect of Vitamin E on Glutathione-Dependent Enzymes, Drug Metabolism Reviews, 35:2-3, 215-253, DOI: 10.1081/DMR-120024086

To link to this article: https://doi.org/10.1081/DMR-120024086

曲 Published online: 28 Jul 2003.

Submit your article to this journal ๘

Џll Article views: 259

Q View related articles $\asymp$

4 Citing articles: 10 View citing articles 두 


\title{
Effect of Vitamin E on Glutathione-Dependent Enzymes
}

\author{
Rachel I. M. van Haaften, ${ }^{1, *}$ Guido R. M. M. Haenen, ${ }^{1}$ \\ Chris T. A. Evelo, ${ }^{2}$ and Aalt Bast ${ }^{1}$ \\ ${ }^{1}$ Department of Pharmacology and Toxicology, Faculty of Medicine, \\ Universiteit Maastricht, Maastricht, The Netherlands \\ ${ }^{2}$ BiGCaT Bioinformatics Group, Universiteit Maastricht and Technische \\ Universiteit, Maastricht, The Netherlands
}

\begin{abstract}
Reactive oxygen species and various electrophiles are involved in the etiology of diseases varying from cancer to cardiovascular and pulmonary disorders. The human body is protected against damaging effects of these compounds by a wide variety of systems. An important line of defense is formed by antioxidants. Vitamin E (consisting of various forms of tocopherols and tocotrienols) is an important fat-soluble, chainbreaking antioxidant. Besides working as an antioxidant, this compound possesses other functions with possible physiological relevance. The glutathione-dependent enzymes form another line of defense. Two important enzymes in this class are the free radical reductase and glutathione S-transferases (GSTs). The GSTs are a family of phase II detoxification enzymes. They can catalyze glutathione conjugation with various electrophiles. In most cases the electrophiles are detoxified by this conjugation, but in some cases the electrophiles are activated. Antioxidants do not act in isolation but form an intricate network. It is, for instance, known that vitamin $\mathrm{E}$, together with glutathione (GSH) and a membrane-bound heat labile GSH-dependent factor, presumably an enzyme, can prevent damaging effects of reactive oxygen species on polyunsaturated fatty acids in biomembranes (lipid peroxidation). This manuscript reviews the interaction between the two defense systems, vitamin $\mathrm{E}$ and
\end{abstract}

*Correspondence: R. I. M. van Haaften, Department of Pharmacology and Toxicology, Faculty of Medicine, Universiteit Maastricht, P.O. Box 616, 6200 MD Maastricht, The Netherlands; Fax: +31 43 3884149; E-mail: Rachel.vanHaaften@BiGCaT.unimaas.nl.

DOI: $10.1081 / \mathrm{DMR}-120024086$

Copyright (C) 2003 by Marcel Dekker, Inc.
0360-2532 (Print); 1097-9883 (Online) www.dekker.com 
glutathione-dependent enzymes. On the simplest level, antioxidants such as vitamin E have protective effects on glutathione-dependent enzymes; however, we will see that reality is somewhat more complicated.

Key Words: Vitamin E; Tocopherol; Tocotrienol; Glutathione; Glutathione-dependent enzymes.

\section{FREE RADICALS AND RELATED "REACTIVE SPECIES"}

The human body is exposed to a huge number of compounds. By themselves most of these compounds are not harmful, but upon metabolic activation some can become toxic. Oxygen is such a compound. During metabolism of oxygen, most of it is bound to hydrogen during oxidative phosphorylation, forming water. However, $4-5 \%$ of the consumed oxygen is not completely reduced to water, but forms hydrogen peroxide or free radicals. A free radical is defined as any species capable of independent existence that contains one or more unpaired electrons. Due to the unpaired electron(s) these molecules can be very reactive.

The partly reduced forms of oxygen formed are called Reactive Oxygen Species (ROS). This is a collective term not only for oxygen radicals but also for some nonradical reactive derivatives of oxygen. Besides ROS, Reactive Nitrogen Species (RNS) also exist. Important ROS/RNS are the superoxide radical, hydroxyl radical, hydrogen peroxide, hypochlorous acid, singlet oxygen, and peroxynitrite. These compounds have different reactivity. The hydroxyl radical is the most reactive compound; it has a high oxidizing capacity. Although hydrogen peroxide is a powerful oxidant, it is relatively unreactive towards most biological substrates unless it is present in unphysiologically high concentrations. A list of reactive oxygen and nitrogen species is given in Table 1. Reactive Oxygen Species and RNS are also called oxidants or pro-oxidants due to the capability of oxidizing biomolecules.

Table 1. Reactive oxygen and reactive nitrogen species.

\begin{tabular}{ll}
\hline Radicals & \multicolumn{1}{c}{ Nonradicals } \\
\hline $\begin{array}{l}\text { Reactive oxygen species (ROS) } \\
\text { Superoxide }\left(\mathrm{O}_{2}^{--}\right)\end{array}$ & Hydrogen peroxide $\left(\mathrm{H}_{2} \mathrm{O}_{2}\right)$ \\
Hydroxyl $\left(\mathrm{OH}^{-}\right)$ & Hypochlorous acid $(\mathrm{HOCl})$ \\
Peroxyl $\left(\mathrm{RO}_{2}^{-}\right)$ & Hypobromous acid $(\mathrm{HOBr})$ \\
Alloxyl $\left(\mathrm{RO}^{-}\right)$ & Ozone $\left(\mathrm{O}_{3}\right)$ \\
Hydroperoxyl $\left(\mathrm{HO}_{2}^{-}\right)$ & Singlet oxygen $\left({ }^{1} \mathrm{O}_{2}\right)$ \\
Reactive nitrogen $\left.\mathrm{species}^{-} \mathrm{RNS}\right)$ & \\
Nitric oxide $\left(\mathrm{NO}^{\circ}\right)$ & Nitrous acid $\left(\mathrm{HNO}_{2}\right)$ \\
Nitrogen dioxide $\left(\mathrm{NO}_{2}^{-}\right)$ & Nitrosyl cation $\left(\mathrm{NO}^{+}\right)$ \\
& Nitroxyl anion $\left(\mathrm{NO}^{-}\right)$ \\
& Peroxynitrite $\left(\mathrm{ONOO}^{-}\right)$ \\
& Peroxynitrous acid $(\mathrm{ONOOH})$ \\
& Alkyl peroxynitrite $(\mathrm{ROONO})$ \\
\hline
\end{tabular}


The human body itself produces certain ROS and RNS, and these reactive species fulfill several pivotal physiological functions. The reactivity of oxygen is, for instance, utilized by the cytochrome P450 enzyme system for hydroxylation of relatively inert endogenous compounds and xenobiotics. Various phagocytic cells are able to produce hypochlorous acid $(\mathrm{HOCl})$, which plays an important role in their bactericidal action. $\mathrm{NO}^{*}$ and $\mathrm{O}_{2}^{-}$also play an important role in the regulation of the contraction tone of the smooth muscle of blood vessels (Bast and Haenen, 1991; Bast et al., 1991).

Beside their physiological functions, ROS and RNS can damage virtually all compounds occurring in living organisms, including DNA, proteins, carbohydrates, and lipids. Damage to these major biomolecules may contribute to the development of aging and multiple diseases such as cancer, cardiovascular and neurological diseases, or emphysema.

Polyunsaturated fatty acids (PUFAs) in the cell membrane are important targets for the reactive species. Radicals may initiate peroxidation of PUFAs. In this process of lipid peroxidation (Fig. 1) the attacking free radical abstracts a hydrogen atom from a PUFA. The formed lipid radical can be delocalized over various structures and in this way resonance stabilized. The lipid radical reacts rapidly with oxygen, producing a peroxyl radical. Subsequently, the lipid peroxyl radical abstracts a hydrogen atom from an adjacent PUFA, and a lipid hydroperoxide, and a new lipid radical are formed. The new lipid radical reacts again with oxygen, is transformed into another lipid hydroperoxide, and generates again a lipid radical. The propagation or chain reaction is interrupted when two unpaired electrons meet and form an even-electron species (termination) or when a relatively unreactive radical is formed. Products, which are formed during this process, include 2-alkenals,

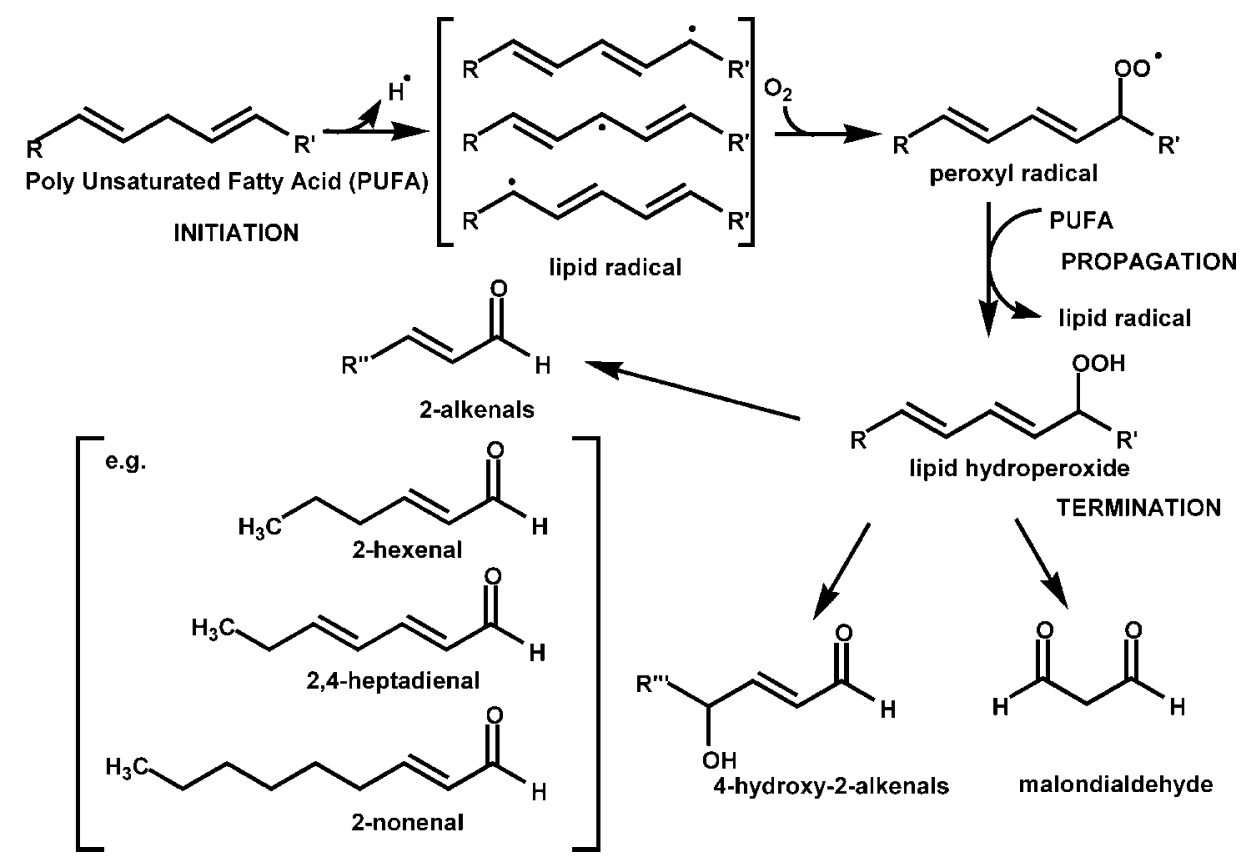

Figure 1. Process of lipid peroxidation and formation of toxic substances. 
4-hydroxy-2-alkenals, and malondialdehyde. These products can be toxic; malondialdehyde (MDA) can react with DNA bases and introduce mutagenic lesions resulting in different types of diseases (Shuker et al., 2002), and 4-hydroxy-2-nonenal (a form of 4hydroxy-2-alkenal) can inhibit cell growth, and display genotoxic activity.

The lipid hydroperoxide can also be cleaved to form radicals that start a new radical chain reaction. This process is called "lipid-hydroperoxide-dependent" lipid peroxidation. When the chain reaction is induced by radicals not originating from lipid hydroperoxides the process is called lipid-hydroperoxide-independent lipoid peroxidation (Girotti, 1985).

\section{ANTIOXIDANT DEFENSE}

To protect against the damaging actions of ROS and RNS, the human body contains an intricate network of antioxidants. The term antioxidant has been defined as "any substance that, when present at low concentrations compared with those of an oxidisable substrate, significantly delays or prevents oxidation of that substrate" (Halliwell, 1995). Antioxidants can be classified by function in categories (Chaudiere and Ferrari Iliou, 1999; Evans and Halliwell, 2001; Noguchi et al., 2000; Sies et al., 1992) (Table 2). The first category is formed by the enzymatic antioxidants. This category of antioxidants is designed by nature to cope with superoxide and hydroperoxides (hydrogen peroxide). Superoxide is degraded by superoxide dismutase (SOD) into hydrogen peroxide and oxygen. Catalase is able to degrade hydrogen peroxide, and glutathione peroxidase (GPX) degrades hydrogen peroxide and organic hydroperoxides. The second category is formed by the nonenzymatic antioxidants and is composed of low molecular weight antioxidants that can be divided into hydrophilic (e.g., vitamin C, glutathione, and flavonoids) and hydrophobic antioxidants (e.g., carotenoids, vitamin E, flavonoids, and ubiquinol-10). Hydrophilic antioxidants are found in cytosolic, mitochondrial, and nuclear aqueous compartments of the cells, while hydrophobic antioxidants are present in lipoproteins and membranes. The reaction kinetics of the nonenzymatic antioxidants is very fast, much faster than reactions of ROS/RNS with other biological targets (Halliwell and Gutteridge, 1999).

A third category of antioxidant defense is formed by compounds able to sequester transition metals. Traces of transition metal ions such as iron and copper can transform hydrogen peroxide into a hydroxyl radical, which is a highly oxidizing compound. This reaction is called the Fenton reaction [Eq. (1)] and proceeds as follows:

$$
\mathrm{Fe}^{2+}+\mathrm{H}_{2} \mathrm{O}_{2} \longrightarrow \mathrm{Fe}^{3+}+\mathrm{OH}^{-}+\mathrm{OH}^{-}
$$

Proteins such as transferrin, ferritin, and ceruloplasmin prevent the formation of hydroxyl radicals by sequestering of transition metals.

The overall function of antioxidants is acting as a coordinated and balanced network to protect tissues and body fluids from damage by ROS and RNS. Disturbance of the balance between oxidants and antioxidants in favor of the oxidants is called oxidative stress (Sies et al., 1992). This will promote damage to important cellular compounds. When this damage occurs at a relatively low level, the human body is able to repair or replace the attacked substrates with the help of several kinds of repair enzymes (Evans and Halliwell, 2001). 
Table 2. Antioxidant defense.

\begin{tabular}{ll}
\hline Enzymatic antioxidants & \multicolumn{1}{c}{ Reaction } \\
\hline Enzyme & \multicolumn{1}{c}{ R } \\
\hline Superoxide dismutase (SOD) & $2 \mathrm{O}_{2}^{--}+2 \mathrm{H}^{+} \rightarrow \mathrm{H}_{2} \mathrm{O}_{2}+\mathrm{O}_{2}$ \\
Glutathione peroxidase (GPX) & $2 \mathrm{GSH}+\mathrm{H}_{2} \mathrm{O}_{2} \rightarrow \mathrm{GSSG}+\mathrm{H}_{2} \mathrm{O}$ \\
& $2 \mathrm{GSH}+\mathrm{ROOH} \rightarrow \mathrm{GSSG}+\mathrm{ROH}+\mathrm{H}_{2} \mathrm{O}$ \\
Catalase & $2 \mathrm{H}_{2} \mathrm{O}_{2} \rightarrow \mathrm{O}_{2}+2 \mathrm{H}_{2} \mathrm{O}$ \\
\hline
\end{tabular}

Nonenzymatic antioxidants (low molecular weight antioxidants)

\begin{tabular}{ll}
\hline Hydrophilic & Hydrophobic \\
\hline Vitamin C & Carotenoids \\
Glutathione & Vitamin E \\
Flavonoids & Flavonoids \\
& Ubiquinol-10 \\
\hline
\end{tabular}

Sequestration of transition metal ions

\begin{tabular}{lc}
\hline Protein & Metal ion \\
\hline Transferrin & $\mathrm{Fe}$ \\
Ferritin & $\mathrm{Fe}$ \\
Ceruloplasmin & $\mathrm{Cu}$ \\
\hline
\end{tabular}

Repair systems

Excision repair and replacement of damaged bases in DNA Increased turnover of damaged proteins

\section{VITAMIN E}

\subsection{Introduction}

Vitamin E was discovered in 1922 by Evans and Bishop to be an essential factor in reproduction (Evans and Bishop, 1922). Absence of this dietary factor caused fetal death and resorption in laboratory rats. Mason showed that vitamin $\mathrm{E}$ is essential for spermatogenic activity (Mason, 1933). Because of this function vitamin E was first designated as the antisterility vitamin. In 1936 Evans, Emerson, and Emerson isolated a small amount of pure vitamin E from wheat germ oil and named it tocopherol (Evans et al., 1936). Fernholz (1938) elucidated the chemical structure of tocopherol.

Vitamin $\mathrm{E}$ is the term used for two groups of closely related, fat-soluble compounds, the tocopherols and the tocotrienols. Both tocopherols and tocotrienols consist of a chroman head (with two rings: one heterocyclic and one phenolic) and a carbon tail attached at the 2-position of the head. The difference between tocopherols and tocotrienols is formed in the carbon-tail; tocopherols contain a saturated phytyl tail and tocotrienols 

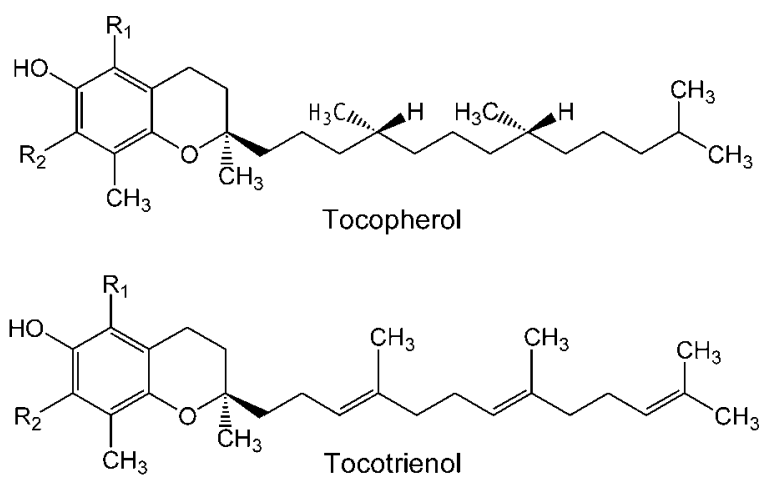

\begin{tabular}{|c|cc|}
\hline & $\mathrm{R}_{1}$ & $\mathrm{R}_{2}$ \\
\hline$\alpha$ & $\mathrm{CH}_{3}$ & $\mathrm{CH}_{3}$ \\
$\beta$ & $\mathrm{CH}_{3}$ & $\mathrm{H}$ \\
$\gamma$ & $\mathrm{H}$ & $\mathrm{CH}_{3}$ \\
$\delta$ & $\mathrm{H}$ & $\mathrm{H}$ \\
\hline
\end{tabular}

Figure 2. Molecular structures of tocopherols and tocotrienols. The naturally occurring vitamers $\alpha, \beta, \gamma$, and $\delta$ have methylation patterns as indicated.

contain three isolated double bonds in their isoprenoid tail (Fig. 2). The names tocopherol and tocotrienol are derived from the Greek words tokos (childbirth), pherein (to bring forth), and trien (three unsaturated bonds); the $-o l$ ending is added to indicate the hydroxyl substituent of the molecules. Both groups consist of four different analogs i.e., $\alpha-, \beta-, \gamma-$, and $\delta$-tocopherol or tocotrienol and are called vitamers. These vitamers differ in the number and position of the methyl substituents attached to the chomanol ring. Due to the three chiral centers present at positions 2 in the chroman ring and $4^{\prime}$ and $8^{\prime}$ in the phytyl tail of tocopherol there are eight possible stereoisomers possible of each tocopherol vitamer. All naturally occurring tocopherols $(\alpha-, \beta-, \gamma-$, and $\delta-)$ have the RRR configuration and are often denoted as d-tocopherol. The synthetic form of $\alpha$-tocopherol, all-rac- $\alpha$-tocopherol or dl- $\alpha$-tocopherol, is normally an equimolar mixture of the eight different stereoisomers (Kamal-Eldin and Appelqvist, 1996; Wang and Quinn, 1999).

Tocotrienols only have one chiral center at position two, so there are only two stereoisomers. The presence of the double bonds at positions $3^{\prime}$ and $7^{\prime}$ in the tail allows, however, for the existence of four cis/trans geometrical isomers per tocotrienol (Kamal-Eldin and Appelqvist, 1996).

\subsection{Uptake and Metabolism}

Since vitamin $\mathrm{E}$ is a vitamin, it has to be acquired from foods or supplements. The main sources of vitamin $\mathrm{E}$ are vegetables and seed oils, whereas animal products are generally pour sources of this vitamin. The natural sources of tocopherol mainly consist of nuts and common vegetable oils (i.e., wheat germ and sunflower). Tocotrienols have 
a relatively high abundance in cereal grains (i.e., oat, barley, and rye) and certain vegetable oils (i.e., palm oil and rice bran oil) (Theriault et al., 1999). There exists a strong correlation between the amount of unsaturated fatty acids in plant oils and its tocopherol content (Bauernfeind, 1977). Of all forms of vitamin E, $\alpha$-tocopherol and $\gamma$-tocopherol are the vitamers present in the highest amounts in the human diet. When vitamin $\mathrm{E}$ is provided as a supplement or added to a product, e.g., a cosmetic product, the hydroxyl group in the phenolic ring of the chroman head is frequently blocked. Sequestration of this group (e.g., by esterification with acetate or succinate) renders the molecule less vulnerable to oxidation. In vivo, the ester is saponified by an esterase, e.g., in the gut lumen, revealing the hydroxyl group (Bjorneboe et al., 1990; Cheeseman et al., 1995).

Dietary vitamin $E$ is absorbed in the small intestine, in the unesterified form, where it is incorporated into chylomicrons. These are transported via the lymph and released into the circulation. The chylomicrons also contain triacylglycerols, which are hydrolyzed by the endothelial-bound lipoprotein lipase. Consequently, the chylomicron remnant, with the incorporated vitamin E, is formed. These chylomicron remnants reach the liver. The liver contains a protein, $\alpha$-tocopherol transfer protein ( $\alpha$-TTP), which is able to selectively sort out RRR- $\alpha$-tocopherol from all incoming tocopherols (Burton and Traber, 1990; Sato et al., 1991). The other forms of vitamin $E$ have lower affinities for this protein. Relative affinity compared to RRR- $\alpha$-tocopherol are: $\beta$-tocopherol, 38\%; $\gamma$-tocopherol, $9 \%$; $\delta$-tocopherol, 2\%; SRR- $\alpha$-tocopherol, $11 \%$; $\alpha$-tocotrienol, $12 \%$; and an esterified form of the vitamin, $\alpha$-tocopherol-acetate, $2 \%$ (Hosomi et al., 1997).

Due to its lipophilic character, vitamin $\mathrm{E}$ is very poorly soluble in the hydrophilic milieu of blood plasma, cytosol, and extracellular fluids. Therefore, vitamin E is (like other lipophilic vitamins) bound to specific proteins or lipoproteins during absorption, transport, and distribution. The sorted RRR- $\alpha$-tocopherol is incorporated into very-lowdensity lipoproteins (VLDL). The other forms of vitamin E with lower affinity for $\alpha$-TTP are metabolized and finally excreted via the bile or the urine. Vitamin E bound to VLDL is secreted from the parenchymal cells and metabolized by lipoprotein lipase. Some of the vitamin $\mathrm{E}$ associated with chylomicrons and VLDL is transferred to peripheral cells and high-density lipoproteins (HDL) during lipolysis. Vitamin E in VLDL ends up in lowdensity lipoproteins (LDL) due to metabolism of VLDL. This LDL-associated vitamin E is taken up by receptor-mediated uptake of LDL in peripheral cells (Bjorneboe et al., 1990; Drevon, 1991; Parker, 1989; Traber and Arai, 1999). In the plasma, vitamin E is transported via binding to lipoproteins. The intracellular transport of vitamin E, e.g., between membrane compartments, is facilitated by tocopherol-associated proteins (TAPs). These TAPs may also act as a molecular chaperone that protects tocopherol from tocopherol-metabolizing enzymes, and may be involved in the alpha-tocopherol mediated cell signaling (Azzi et al., 2001). Tocopherol-associated protein have as the TTP the highest affinity for RRR- $\alpha$-tocopherol compared to the other forms of vitamin E (Zimmer et al., 2000).

The normal plasma level of vitamin $\mathrm{E}$ is between $23 \mu \mathrm{M}$ and $35 \mu \mathrm{M}$ (Kappus and Diplock, 1992; Traber et al., 2001). Genetic defects in $\alpha$-TTP can lead to plasma vitamin E levels as low as $1 \%$ of the normal concentrations. People with this genetic defect have neurological abnormalities that are characterized by dying of the axons of the sensory neurons, resulting in ataxia, muscle inclusions, and retinal degeneration (Krendel et al., 1987; Laplante et al., 1984; Larnaout et al., 1997; Stumpf et al., 1987). This characteristic syndrome 
is called ataxia with vitamin E deficiency (AVED), previously called familial isolated vitamin E (FIVE) (Parks and Traber, 2000; Traber and Arai, 1999). When people with this disorder are supplemented with $\alpha$-tocopherol, the plasma concentrations reach normal levels within hours, but quickly decline when supplementation is stopped. The temporary increase in plasma concentration due to supplementation is caused by nonspecific redistribution of $\alpha$ tocopherol to peripheral cells from chylomicrons (left broken arrow in Fig. 3) (Blatt et al., 2001).

The forms of vitamin $\mathrm{E}$ that are not taken up by the liver are finally excreted (as described above) by the bile or via the urine. Mechanisms of transport of vitamin E via the bile are not known. Before urinary excretion vitamin $\mathrm{E}$ is extensively metabolized. Tocopherols and tocotrienols are metabolized by side-chain degradation via $\omega$ hydroxylation and $\beta$-oxidation (Fig. 4). The initial step, the $\omega$-hydroxylation of the sidechain, is performed by CYP4F2, a cytochrome P450 (CYP)-dependent hydroxylase. This hydroxylase also catalyses $\omega$-hydroxylation of leukotriene $\mathrm{B}_{4}$ and arachidonic acid (Sontag and Parker, 2002). The $\omega$-hydroxylation is followed by five $\beta$-oxidation cycles (Brigelius Flohe and Traber, 1999; Brigelius Flohe et al., 2002; Houte van et al., 2001; Pope et al., 2001). Final products, carboxyethyl hydroxychromans (CEHCs), are excreted via the urine (Parker and Swanson, 2000). Enzymes involved in the degradation of unsaturated fatty acids (2,4-dienoyl-CoA reductase and 3,2-enoyl-CoA isomerase) are needed for the degradation of the unsaturated side chain of tocotrienols (Birringer et al., 2002). However, irrespective of the difference in side-chain between tocopherols and tocotrienols, the final products of the metabolism are CEHCs (Birringer et al., 2001).

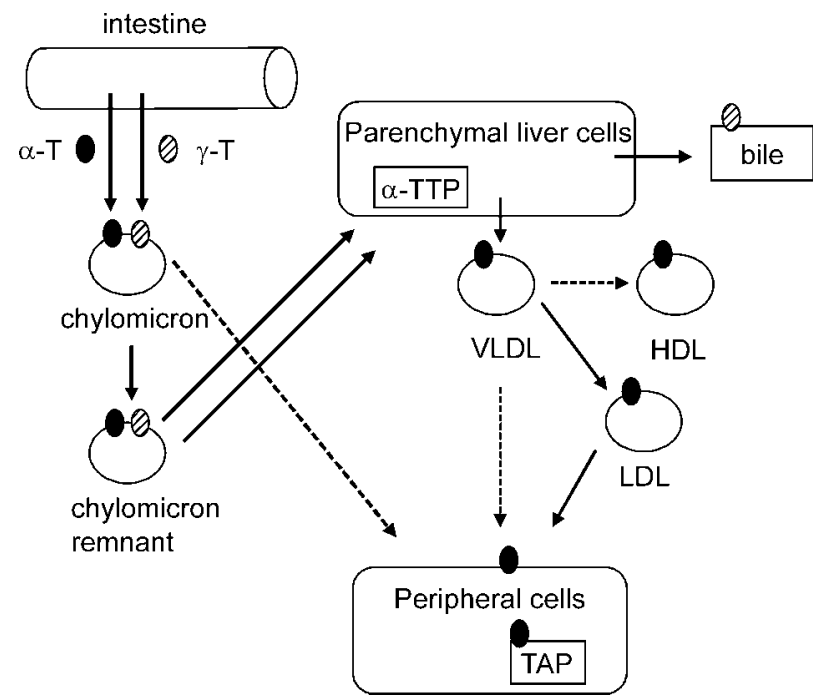

Figure 3. Transport of vitamin $\mathrm{E}$ between different tissues. Black bullet represents RRR $-\alpha$-tocopherol and striped bullet means $\gamma$-tocopherol. 


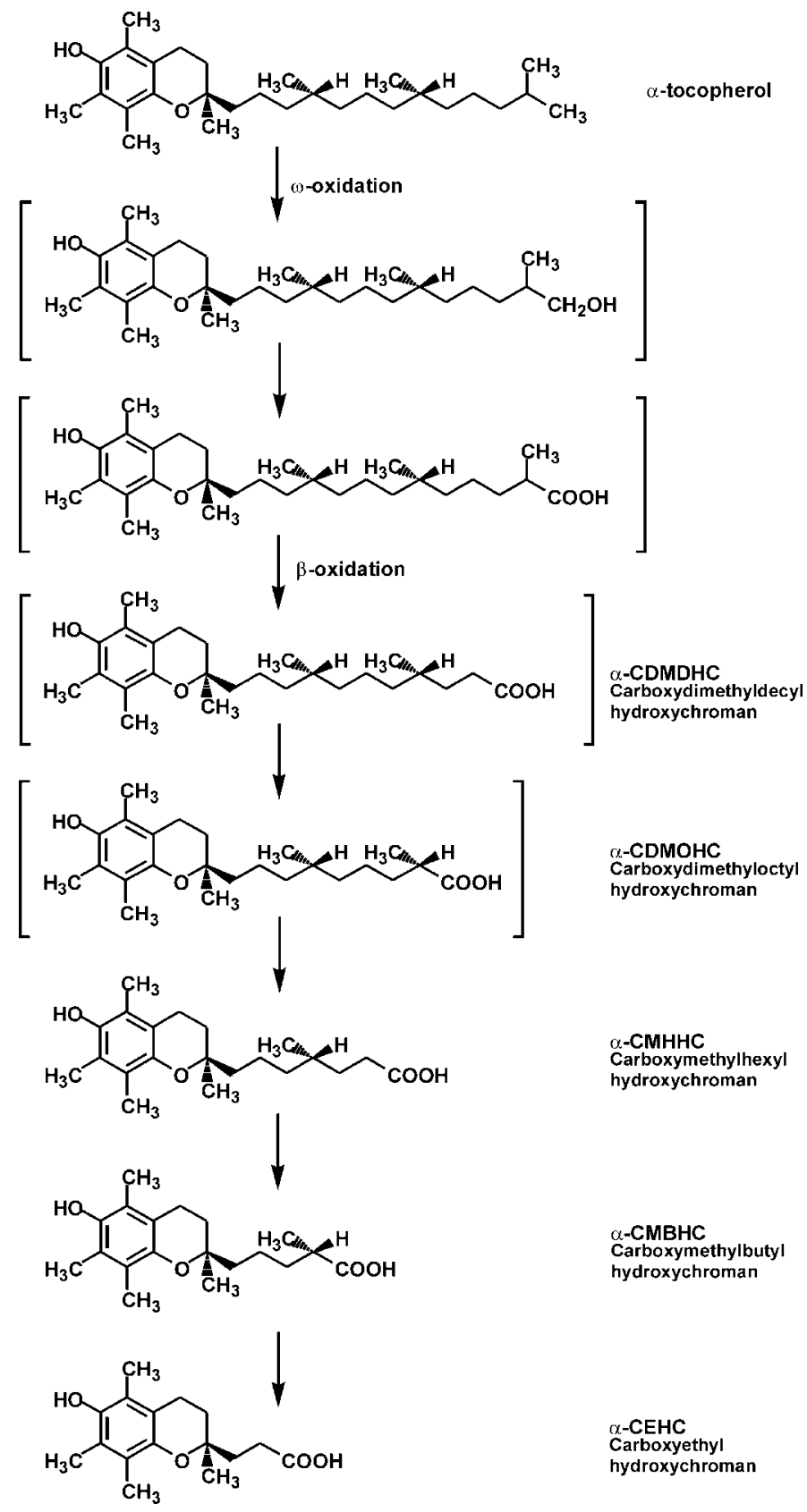

Figure 4. Mechanism of tocopherol side-chain degradation ( $\alpha$-tocopherol is shown as an example). Side-chain degradation starts with $\omega$-oxidation, followed by five $\beta$-oxidation cycles. 


\subsection{Functions of Vitamin $\mathbf{E}$}

\subsubsection{Antioxidant Function}

Both tocopherols and tocotrienols are well recognized for their antioxidative effects. It has been detected that, in vitro, the tocotrienols are more potent antioxidants than the tocopherols (Packer et al., 2001). However, because $\alpha$-tocopherol is the form of vitamin E mostly present in the human body, its antioxidant effect is the most important in the defense against reactive oxygen species of all vitamin E vitamers. The best-known antioxidant function of $\alpha$-tocopherol is scavenging of peroxyl radicals that propagate chains in the nonenzymatic lipid peroxidation (Fig. 5). Tocopherol (1) functions as a chain-breaking antioxidant in the reaction of the hydroxyl group with a peroxyl radical (ROO), either by hydrogen transfer or by sequential electron, then proton transfer to form a lipid hydroperoxide and the tocopheroxyl radical (2).

This radical is a resonance-stabilized radical due to delocalization of the unpaired electron over the chroman head of the molecule, rendering the radical relatively unreactive. Reaction of the tocopheroxyl radical with a peroxyl radical can lead to two groups of products. The first are $8 \alpha$-substituted tocopherones (3), which contain a hydroxyl group or a peroxyl radical-derived adduct in the chroman head. These products lead to the formation of $\alpha$-tocopherol quinone (4). The second group of products is the epoxy- $8 \alpha$-hydroperoxytocopherones (5), which have an epoxide in the chroman head. These compounds hydrolyze and rearrange to epoxy- $\alpha$-tocopherol quinones (6). $\alpha$-Tocopherol quinone can be reduced by a two electron reduction to $\alpha$-tocopherolhydroquinone (7) in cell-free and cellular systems by $\mathrm{NAD}(\mathrm{P}) \mathrm{H}$ :quinone oxidoreductase (Dinkova-Kostova and Talalay, 2000; Hayashi et al., 1992; Siegel et al., 1997). $\alpha$-Tocopherolhydroquinone is very unstable and easily autoxidizes to $\alpha$-tocopherol quinone when exposed to aerobic conditions (Chow, 1983; Hayashi et al., 1992). This autoxidation yields $\alpha$-tocopherol quinone as major product, but also, some epoxy$\alpha$-tocopherol quinones are formed as minor products (Liebler, 1993; Liebler and Burr, 2000). It has been demonstrated that $\alpha$-tocopherol quinone can be recycled to the parent compound $\alpha$-tocopherol in humans (Moore and Ingold, 1997).

Also, during peroxyl radical scavenging tocopherol dimers and trimers can be formed, but these are just minor products (Kamal-Eldin and Appelqvist, 1996; Liebler, 1998; Wang and Quinn, 1999).

Tocopherols also react with a variety of other reactive oxidants such as singlet oxygen (Clough et al., 1979; d'Ischia and Novellino, 1996), alkoxyl radicals (Suarna and Southwell-Keely, 1988; Suarna et al., 1988; Suarna et al., 1992), peroxynitrite (Hogg et al., 1994), nitrogen dioxide (Cooney et al., 1995), ozone (Giamvala et al., 1986; Liebler et al., 1993), and superoxide (Matsuo and Matsumoto, 1987). Reaction of tocopherol with these compounds also contributes to the cellular antioxidant defense (Liebler, 1998; Wang and Quinn, 1999).

Not only does tocopherol contain antioxidant activity, but $\alpha$-tocopherolhydroquinone also can function as an effective antioxidant. Like tocopherol it can inhibit lipid peroxidation (Bindoli et al., 1985; Siegel et al., 1997). Thus the antioxidant activity of tocopherol can be extended to its metabolites (Kohar et al., 1995; Shi et al., 1999). It has even been stated that tocopherolhydroquinone is a much more potent antioxidant in 

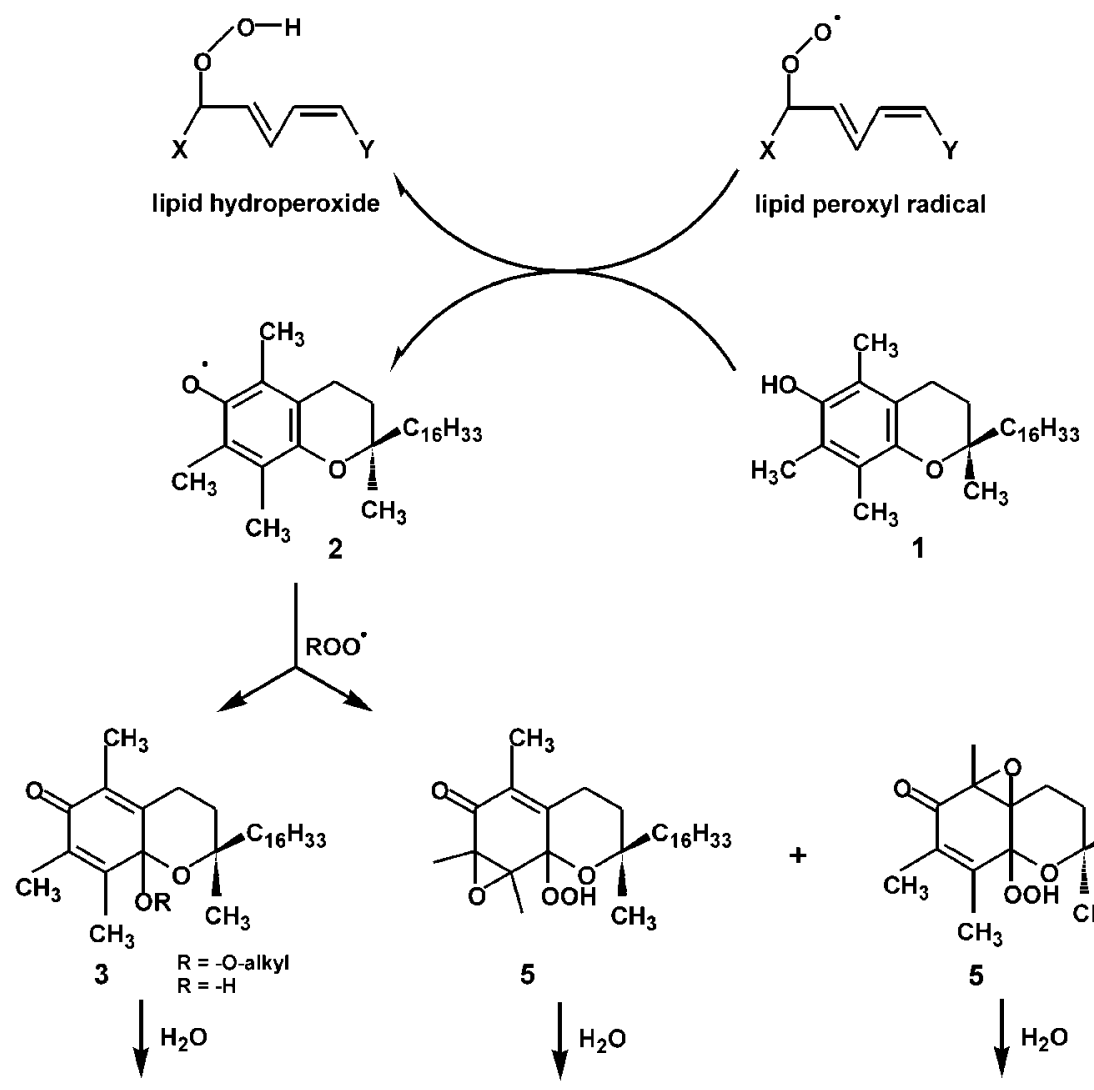

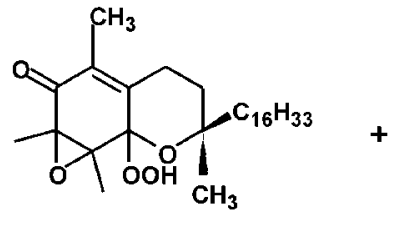

5

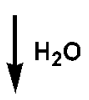

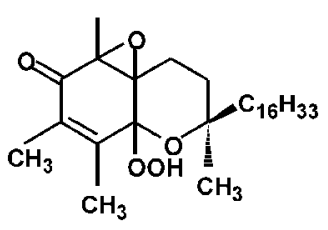

5<smiles>C[14CH2]O</smiles>

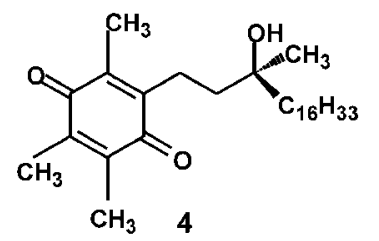

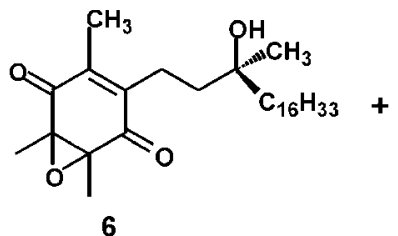

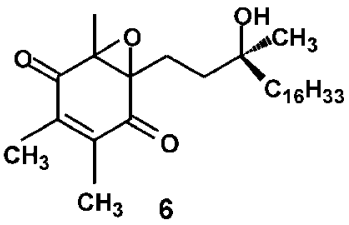

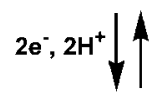<smiles>Cc1c(C)c(O)c(CCC(C)(O)C(C)(C)O)c(C)c1O</smiles>

Figure 5. Reactions of $\alpha$-tocopherol with peroxyl radicals. $1=\alpha$-tocopherol; $2=\alpha$-tocopheroxyl radical; $3=8 \alpha$-substituted tocopherones; $4=\alpha$-tocopherol quinone; $5=$ epoxy- $8 \alpha$ hydroperoxytocopherones; $6=$ epoxy- $\alpha$-tocopherol quinones; $7=\alpha$-tocopherolhydroquinone. 
the lipid peroxidation than tocopherol itself (Bindoli et al., 1985). Tocopherolhydroquinone scavenges peroxyl radicals primarily by electron transfer to form tocopherol quinone. However, the formation of epoxy- $\alpha$-tocopherol quinones suggests that a radical addition/elimination reaction also occurs (Liebler and Burr, 2000).

\subsubsection{Pro-oxidant Activity}

Opposed to the antioxidant effects of vitamin E, alpha-tocopherol can also have a prooxidant effect. This activity is caused by the reaction of $\alpha$-tocopherol with transition metals (e.g., $\mathrm{Cu}^{2+}$ ). The transition metal is reduced and an $\alpha$-tocopheroxyl radical is formed. Both the reduced metal (e.g., $\mathrm{Cu}^{+}$) and the tocopheroxyl radical are able to promote the lipid peroxidation (Eder et al., 2002; Maiorino et al., 1993; Minotti and Aust, 1992). In the CHAOS (Cambridge Heart Antioxidant Study) epidemiological study, an initial increase of fatal myocardial infarctions was observed due to relatively high dose of RRR- $\alpha$-tocopherol supplementation (Stephens et al., 1996). The doses used are approximately 120 and 60 times the Recommended Daily Allowance (RDA) for vitamin E. Halliwell speculated that this increase can be explained by interaction of vitamin $\mathrm{E}$ with transition metal ions present in unstable plaques (pro-oxidant effect) (Halliwell, 2000). The pro-oxidative effects of excessive vitamin E depends on the type of dietary fat. A diet with high content of polyunsaturated fatty acids (PUFA) increases the content of the membrane with PUFA, which makes the membrane much more prone to oxidation (Eder et al., 2002). A diet rich in PUFA and vitamin E can promote the process of lipid peroxidation in smokers (Weinberg et al., 2001).

Antioxidants are converted in oxidation products when they have performed their function as antioxidant. Remarkably, little is known about the toxicity of these metabolites that are formed. It is known that tocopherol quinone, a metabolite of tocopherol formed after antioxidant action, can have a cytotoxic effect. This toxicity is dependent on the ability to generate oxygen radicals, oxidize cellular components, and function as arylating electrophiles, forming Michael adducts with nucleophilic thiol groups. This arylating function of quinone depends on the number and position of substituents in the quinone. The different quinone forms of tocopherol differ in the number and position of methyl groups on the chroman head (Bauernfeind, 1977; Bjorneboe et al., 1990; Drevon, 1991; Kamal-Eldin and Appelqvist, 1996; Meydani, 1995; Theriault et al., 1999; Wang and Quinn, 1999). $\alpha$-Tocopherol quinone, which is fully methylated, is incapable of forming adducts with thiols, while $\gamma$-, and $\delta$-tocopherol quinone, which do not have a completely methylated chroman head, can form these adducts (Cornwell et al., 2002). The difference in the ability of formation of these Michael adducts may be the basis for the difference in cytotoxicity, in cell culture, of various forms of tocopherol quinone. It was shown that $\gamma$-tocopherol quinone but not $\alpha$-tocopherol quinone diminished the number of viable cells and stimulated apoptosis. (Cornwell et al., 1979; 2002; Jones et al., 2002; Lindsey et al., 1985; Thornton et al., 1995). The difference in toxicity between $\alpha$-tocopherol quinone and the other tocopherol quinones was in line with the results of a study performed in 1930 . Experimental animals were fed cod liver oil (contains mainly $\alpha$-tocopherol) or wheat germ oil (contains $\gamma$ - and $\delta$-tocopherol) which was pretreated with $\mathrm{FeCl}_{3}$ to destroy vitamin $\mathrm{E}$. Although at that time it was not realized that tocopherol quinones were formed by 
the pretreatment of the dietary supplements, they undoubtedly were. Animals fed processed cod oil show little toxic effects while animals fed the processed wheat germ oil develop lymphoblastomas or malignant sarcomas (Rowntree et al., 1937; Taylor and Nelson, 1930). The contrasting biological effect between both processed oils may now be explained by the difference in toxicity of the different quinones formed.

\subsubsection{Nonantioxidant Function}

Besides working as an antioxidant or pro-oxidant, multiple other functions of vitamin $\mathrm{E}$ or its metabolites have been described. These functions cannot be assigned to their known antioxidant or pro-oxidant functions and are called the nonantioxidant effects of vitamin E.

For instance, it is known that alpha-tocopherol can activate protein phosphatase $2 \mathrm{~A}$ (PP2A) by binding to specific cellular sites of the protein. As a consequence of this, protein kinase $\mathrm{C} \alpha(\mathrm{PKC} \alpha)$ is dephosphorylated and inhibited, which affects the AP1 transcription factor, resulting in a change in the level of gene transcription and finally inhibition of cell proliferation (especially of vascular smooth muscle cells). $\beta$-Tocopherol shows no effect at the level of cell proliferation or protein kinase $\mathrm{C}$ activity but rather, prevents the effect of $\alpha$-tocopherol (Azzi and Stocker, 2000; Azzi et al., 1993; 1997; 1999; Tasinato et al., 1995; Traber and Packer, 1995).

Vitamin E also plays a central role in cholesterol biosynthesis. Many researchers have shown that tocotrienols modulate the intracellular mechanism for the controlled degradation of 3-hydroxy-3-methylglutaryl coenzyme A (HMG-CoA) reductase, the enzyme controlling the rate of cholesterol synthesis. Tocotrienols inhibit HMG-CoA reductase by reducing synthesis of this protein and increasing the degradation rate of the enzyme, resulting in a decrease of cholesterol levels. In contrast to tocotrienols, tocopherols can increase the hepatic HMG-CoA reductase activity. So the farnesylated side chain of tocotrienols is needed for the inhibition of HMG-CoA reductase (Khor and Ng, 2000; Napoli et al., 1998; Packer et al., 2001; Pearce et al., 1992; 1994; Qureshi et al., 1995; 1996; 2002; Theriault et al., 1999).

It is also described that the final products of $\gamma$-tocopherol metabolism, $\gamma$-CEHC, possess strong natriuretic activity due to inhibition of a $\mathrm{K}^{+}$channel in the thick ascending limb of the kidney. It is proposed that this metabolite of $\gamma$-tocopherol is identical to the low molecular weight "natriuretic hormone," which controls the extracellular fluid in the human body. The body's pool of extracellular fluid is an important determinant in hypertension, congestive heart failure, and cirrhosis (Kantoci et al., 1997; Wechter et al., 1996).

Another nonantioxidant effect of vitamin $\mathrm{E}$ is stabilizing of the membrane (Patel and Edwards, 1988). Vitamin $\mathrm{E}$ integrates in membranes where it forms complexes with membrane lipid components that have a tendency to destabilize the bilayer structure. So the effects of these destabilizing components is counteracted by vitamin E, resulting in a more stable membrane (Wang and Quinn, 1999; 2000).

The first step in the formation of a thrombus is platelet aggregation and adherence to vascular endothelium, forming a fibrous plaque. It is suggested that tocopherols and tocotrienols can have positive effects on platelet adhesion/aggregation due to suppression 
of thromboxane synthesis. There are two mechanisms by which this synthesis can be suppressed by vitamin E. The first is suppression of phospholipase A2, which results in reduction of the release of arachidonic acid (which is a precursor of prostaglandin and eventually thromboxane) from membrane-bound phospholipids. The other mechanism of suppression of thromboxane synthesis is the inhibition of the transcriptional activity of the cyclooxygenase gene. Due to this inhibition the transformation of arachidonic acid into prostaglandins is decreased (Chan, 1998; Jiang et al., 2000; Theriault et al., 1999; Traber and Packer, 1995; Wang and Quinn, 1999; 2000). High plasma levels of apolipoprotein B-100 (apoB), the protein moiety of LDL, are another important risk factor for the development of atherosclerosis. Several epidemiological studies have shown that $\gamma$-tocotrienol can reduce the apoB plasma levels by $10 \%$ to $15 \%$. The mechanism of this reduction is not clear yet, but it is speculated that LDL receptors in the liver are upregulated, facilitating the clearance of LDL-apoB from the bloodstream, or that the production of VLDL and LDL is decreased (Theriault et al., 1999).

As described above, the different forms of vitamin $\mathrm{E}$ can perform multiple roles. Some of these functions are directly or indirectly related to cardiovascular diseases. As antioxidant, vitamin $\mathrm{E}$ can protect against lipid peroxidation and thus decrease the risk for cardiovascular diseases. Acting as a pro-oxidant, vitamin E can increase the risk for cardiovascular diseases and numerous nonantioxidant functions of vitamin $\mathrm{E}$, or its metabolites can play important roles in the development of cardiovascular diseases. In the past, numerous human vitamin $\mathrm{E}$ intervention studies have been performed e.g., the CHAOS and GISSI (Gruppo Italiano per lo Studio della Sopravvivenza nell'Infarto miocardico) intervention studies (Meagher, 2003). The CHAOS study showed a decrease in nonfatal myocardial infarction but a rise in fatal myocardial infarction (Stephens et al., 1996). The GISSI (Prevenzione) studies failed to detect such benefit (Marchioli, 1999; Stephens et al., 1996; Yusuf, 2000). Overall it can be concluded that the outcomes of these different clinical intervention studies present a confused picture (Manson et al., 2003).

\section{GLUTATHIONE AND GLUTATHIONE DEPENDENT ENZYMES}

\subsection{Introduction}

As described in part 2, reduced glutathione (GSH) is an important contributor of the nonenzymatic antioxidant defense mechanism of the body. It is present in millimolar concentrations intracellular and is a versatile and ubiquitous cellular antioxidant (Griffith and Meister, 1979; Liebler, 1993). Glutathione represents at least 90\% of total nonprotein low molecular weight thiols present in cells (Reed and Fariss, 1984). It is a relative simple tripeptide consisting of glutamic acid (Glu), cysteine (Cys), and glycine (Gly) (Fig. 6).

The antioxidant reaction of GSH (reacting with free radicals) generates thiyl radicals (GS), which can react with oxygen to form GS-oxygen conjugates and can form the glutathione disulfide (GSSG) (Wardman, 1988). Less than 5\% of total glutathione in the cells is GSSG (Reed and Fariss, 1984).

Besides working as a scavenger of reactive species, GSH is involved in a variety of other metabolic functions such as DNA repair, activation of transcription factors, cell cycle regulation, modulation of calcium homeostasis, and regulation of enzyme activity. 


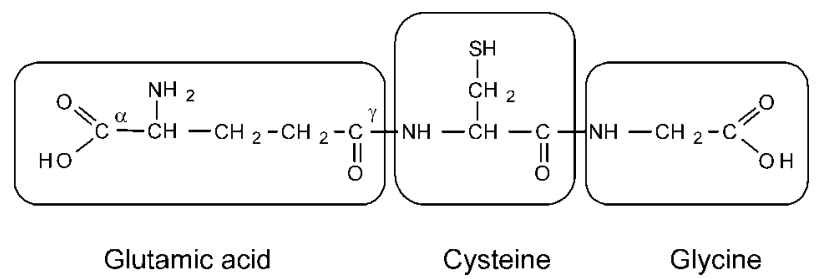

Figure 6. Structure of the tripeptide reduced glutathione (GSH: L- $\gamma$-glutamyl-L-cysteinylglycine).

Most of these functions of glutathione are related to its ability to maintain a reduced cellular environment (Arrigo, 1999).

Glutathione can also play a role in intracellular copper transport and detoxification. Glutathione is used as a substrate by different enzymes involved in cell defense, such as glutathione peroxidases (GPX), glutathione reductase (GRD), gamma-glutamyltranspeptidase (GGT), and glutathione S-transferases (GST) (Fig. 7).

The intracellular glutathione content can be changed by many different conditions. These include the presence of heavy metals, high glucose concentrations, and heat shock. Exposure to reactive oxygen and nitrogen species can increase the GSH content by increasing the rate of GSH synthesis. Due to use and synthesis, a balance in the GSH content in the cell is formed.

\subsection{Uptake and Synthesis}

Substrates for GSH synthesis are provided by transport of amino acids across the plasma membrane or by the action of GGT and dipeptidases. A membrane-bound protein, GGT is found in the serum of a wide range of normal and neoplastic cells (Black and Wolf, 1991; Whitfield, 2001). It catalyzes the first step in the degradation of extracellular GSH. In GSH, the amino acid glutamic acid is bound to the cysteine residue with a gammaglutamyl binding. This Glu-Cys bond is not sensitive for regular proteolysis so GSH cannot be cleaved, which makes the molecule more stable. Gamma-glutamyltranspeptidase is able to hydrolyze the gamma-glutamyl bond between Glu and Cys [Eq. (2)]. In this way cysteinyl-glycine is released, which is subsequently cleaved to Cys and Gly by plasma membrane dipeptidase activities (Griffith and Meister, 1979). These two amino acids can cross the plasma membrane and are again used in the GSH synthesis.

$$
\mathrm{GSH} \stackrel{\text { GGT }}{\longrightarrow} \text { L-glutamate + Cys-Gly }
$$

Thus, the role of GGT would be to preserve cellular levels of GSH by GSH cycling at the plasma membrane (Paolicchi et al., 2002).

The de novo synthesis of GSH results from the effort of two ATP-dependent enzymes, $\gamma$-glutamylcysteine synthetase $(\gamma$-GCS) (also known as glutamate:cysteine ligase) and glutathione synthetase. Glutamylcysteine synthetase is rate limiting for the synthesis of GSH. This enzyme consists of two nonidentical subunits, a heavy subunit and a light subunit (Deneke and Fanburg, 1989; Dickinson and Forman, 2002). The heavy subunit 


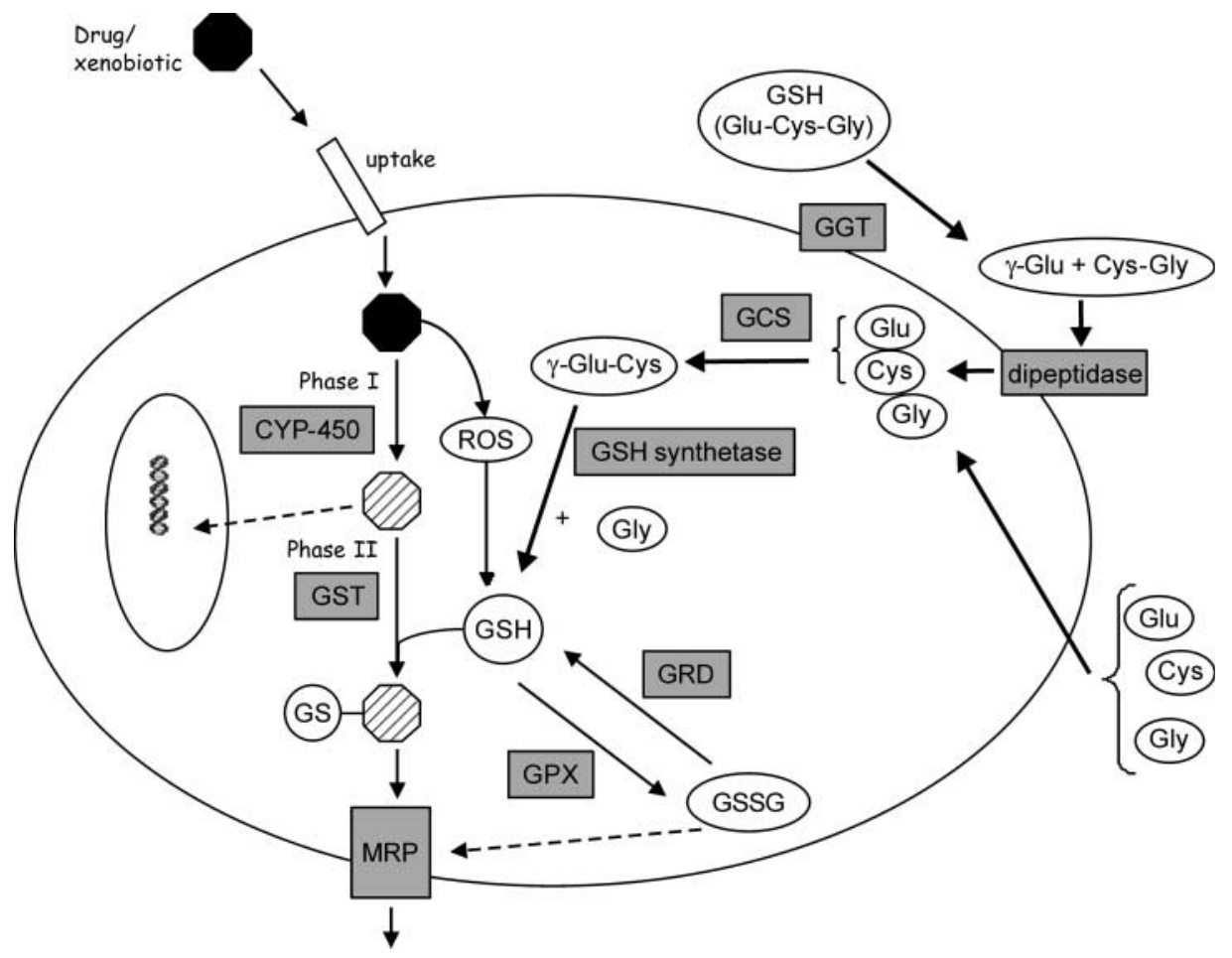

Figure 7. Glutathione metabolism and glutathione-dependent cellular defense mechanisms. Drugs and xenobiotics are taken up by the cell and metabolized by cytochrome P450s. This potentially generates electrophilic cytotoxic intermediates (dashed symbols) and ROS (Phase I). In the detoxification of these products GSH plays an important role. GST catalyzes glutathione conjugation reactions (phase II). These glutathione conjugates are recognized by MRP family members and transported out of the cell. GSH is also important for the GPX-catalyzed reduction of ROS, which results in the formation of GSSG. This is reduced by GRD or excreted via MRP. Substrates for GSH synthesis are provided by transport of amino acids across the membrane or by the action of GGT and dipeptidases. The synthesis of GSH results from the effort of GCS and GSH synthetase. Thick arrows indicate processes involved in GSH synthesis.

contains all structural requirements for the enzymatic activity and feedback inhibition. The function of the light subunit is not directly associated with the enzymatic activity, but it exerts some effect on the stability of the enzyme and on the controlling of the kinetic properties of the heavy subunit (Mulcahy and Gipp, 1995; Seelig et al., 1984; Wild and Mulcahy, 2000). The promoter regions of both subunits contain a number of transcription factor binding sites including activator protein 1 (AP-1), nuclear factor $\kappa \mathrm{B}(\mathrm{NF \kappa B})$, and antioxidant response element (ARE) sites, which are potential targets for regulation of the enzyme (Moellering, 1999). The activity of $\gamma$-GCS is regulated by nonallosteric feedback inhibition by GSH, which means that when the GSH concentration decreases, the feedback inhibition by GSH also decreases and $\gamma$-GCS synthesizes more GSH (Richman and Meister, 1975). 


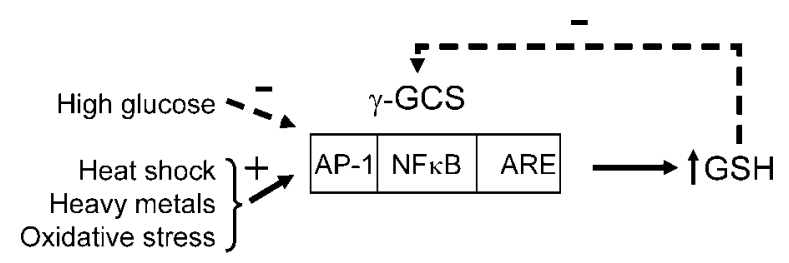

Figure 8. Regulation of GSH concentration by $\gamma$-GCS.

The activity of $\gamma$-GCS can be influenced by many different conditions. High glucose concentration lowers the GSH concentration by decreasing the expression of $\gamma$-GCS mRNA, which leads to a decrease in enzyme protein and enzyme activity (Urata et al., 1996). The GSH concentration can be increased by heat shock (Kondo et al., 1993), heavy metals (Woods and Ellis, 1995), and oxidative stress, e.g., $\mathrm{NO}^{\circ}$ or $\mathrm{H}_{2} \mathrm{O}_{2}$ (Moellering, 1999; Rahman et al., 1996). Due to these different conditions the transcriptional levels of $\gamma$-GCS increase, the $\gamma$-GCS activity increases, and more GSH is produced (Fig. 8).

\subsection{Functions of Glutathione}

\subsubsection{Enzyme Substrate}

Various enzymes involved in cell defense use GSH as a substrate. The most important ones are described below.

\subsection{1a. Glutathione Peroxidase (GPX)}

Glutathione peroxidase (GPX) catalyzes the reduction of a large variety of hydroperoxides into their corresponding, less reactive, alcohols at the expense of GSH, which is oxidized to GSSG. Distinct families of enzymes display GPX activity; these can be classified as selenium-dependent and selenium-independent (Douglas, 1987; Flohe, 1988; Hayes and McLellan, 1999). The selenium-dependent enzymes are formed by the classical glutathione peroxidases (GPX) (Mills, 1957) and the phospholipid hydroperoxide GPX (PLHG-PX), originally called peroxidation inhibiting protein (PIP) (Ursini et al., 1982); the selenium-independent enzymes are formed by glutathione-S-transferases (GST). The enzymes can be distinguished by different substrate selectivity (Hayes and McLellan, 1999). Both selenium-dependent glutathione peroxidases use hydrogen peroxide and organic hydroperoxides as substrate [Eqs. $(3,4)]$. Phospholipid hydroperoxides can only directly be accepted as substrate by PLHG-PX (Ursini et al., 1982). In order to detoxify phospholipid hydroperoxide by the classical selenium-dependent GPX; it has to be deacylated by phospholipase $\mathrm{A}_{2}$. A lysophospholipid and a free lipid hydroperoxide are formed, which can be converted via the classical selenium-dependent GPX (McCay et al., 1976).

$$
\begin{aligned}
& 2 \mathrm{GSH}+\mathrm{ROOH} \stackrel{\mathrm{GPX}}{\longrightarrow} \mathrm{GSSG}+\mathrm{H}_{2} \mathrm{O}+\mathrm{ROH} \\
& 2 \mathrm{GSH}+\mathrm{H}_{2} \mathrm{O}_{2} \stackrel{\mathrm{GPX}}{\longrightarrow} \mathrm{GSSG}+2 \mathrm{H}_{2} \mathrm{O}
\end{aligned}
$$



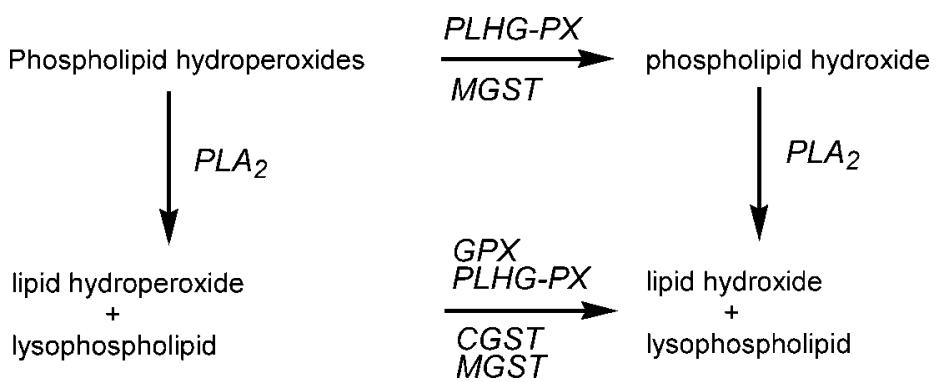

Figure 9. Reduction of phospholipid hydroperoxides by GPXs and phospholipase $\mathrm{A}_{2}\left(\mathrm{PLA}_{2}\right)$.

The selenium-independent glutathione peroxidase (GST) is only active with organic hydroperoxides; they are inactive with hydrogen peroxide. The GST-catalyzed reaction between hydroperoxide and GSH is performed in two steps (Flohe, 1988). The first one is catalyzed by GST as show in Eq. (5)

$$
\mathrm{GSH}+\mathrm{ROOH} \stackrel{\mathrm{GST}}{\longrightarrow} \mathrm{GSOH}+\mathrm{ROH}
$$

This reaction is followed by a nonenzymatic reaction of sulfenic acid with GSH [Eq. (6)] (Prohaska, 1980).

$$
\mathrm{GSOH}+\mathrm{GSH} \longrightarrow \mathrm{GSSG}+\mathrm{H}_{2} \mathrm{O}
$$

Phospholipid hydroperoxide can only be detoxified by the selenium-independent class of enzymes via phospholipase $\mathrm{A}_{2}$. However, the membrane-bound form of GST is able to reduce phospholipid hydroperoxides without the participation of phospholipase $\mathrm{A}_{2}$ (Sevanian et al., 1983).

Glutathione peroxidase activity can, either alone or in combination with phospholipase $\mathrm{A}_{2}$, form an important defense mechanism against "lipid-hydroperoxidedependent" lipid peroxidation (McCay et al., 1976; Sevanian et al., 1983) (Fig. 9). So GPX is used for the protection and detoxification of biomembranes and for maintaining the structural and functional integrity of the cytosolic compartment.

\subsection{1b. Glutathione Reductase (GRD)}

Glutathione reductase (GRD) has a disulfide in its catalytic site. The enzyme exists as a dimer of two identical subunits (Black and Wolf, 1991; Douglas, 1987). The cellular function of GRD is to maintain the GSH:GSSG ratio at about 20:1. This is achieved by using NADPH as coenzyme in the reduction of GSSG to GSH [Eq. (7)].

$$
\mathrm{NADPH}+\mathrm{H}^{+}+\mathrm{GSSG} \stackrel{\mathrm{GRD}}{\longrightarrow} \mathrm{NADP}^{+}+2 \mathrm{GSH}
$$

In normal cases the reduction of GSSG by glutathione reductase is relatively rapid, but in cases of oxidative stress GSSG can accumulate. In this case GSSG is either transported from the cells or can exchange with protein sulfhydryls to produce protein-glutathione 
mixed disulfides [Eq. (8)] (Brigelius et al., 1983):

$$
\mathrm{GSSG}+\text { protein-SH } \leftrightarrows \text { protein-SSG + GSH }
$$

\subsection{1c. Glutathione S-transferase (GST)}

Glutathione S-Transferase is a superfamily of phase II enzymes, which in humans consists of the cytosolic GSTs [alpha (A), mu (M), omega (O), pi (P), theta (T), and zeta (Z)] (Awasthi et al., 1994; Board et al., 1997; Eaton and Bammler, 1999), three microsomal GSTs (MGST 1, MGST 2, and MGST 3) and one mitochondrial GST [kappa (K)], each of which displays distinct catalytic as well as binding properties (Awasthi et al., 1994; Board et al., 2000; Eaton and Bammler, 1999).

The microsomal GSTs are members of the MAPEG (membrane-associated proteins in eicosanoid and glutathione metabolism) family, which consists of six human proteins. The proteins within this family that contain GST activity are microsomal GST 1 (MGST 1), MGST 2, and MGST 3.

A standardized nomenclature for human GSTs was introduced in 1992 by Mannervik et al. and was extended in 1995 by Hayes and Pulford. This nomenclature identifies each GST by species using lower case letter(s) preceding "GST" (h for human, $\mathrm{r}$ for rat, $\mathrm{m}$ for mouse, etc.). This is followed by an upper case letter denoting the class (A, M, O, P, T, Z), then an Arabic numeral indicating the subunit $(1,2,3 \ldots)$ and in a few cases a lower case letter for the allelic variants of the same gene (a, b, c...).

All isoenzymes of GST exist as multimeric proteins. The cytosolic GSTs appear as dimeric proteins with subunits of approximately $25 \mathrm{kDa}$ (Jakoby, 1978). The microsomal GSTs exists as a trimer of three identical polypeptides each of 17.2 kDa (Lundqvist et al., 1992). Only the subunits within each class hybridize in the cytosolic GSTs to give active dimers (Awasthi et al., 1994). Each subunit of the enzyme has an active site composed of two distinct functional regions - a hydrophilic $\mathrm{G}$ site that binds the physiological substrate GSH, and a hydrophobic $\mathrm{H}$ site that is responsible for the binding and orientation of structurally diverse electrophilic substrates (Ketterer, 1998; Mannervik, 1985). Only about $30 \%$ sequence similarity exists among the different isoenzymes, but their quaternary structure is remarkably similar (Salinas and Wong, 1999).

The first and most important function of the enzyme is conjugation of electrophilic compounds with GSH [Eq. (9)]. GST brings the substrate (electrophilic compound) into close proximity with GSH by binding both the substrate and GSH. The thiol of GSH is first activated to the thiolate anion $\left(\mathrm{GS}^{-}\right)$to increase its nucleophilicity. The thiolate anion attacks the electrophilic substrate (R-X) with a GSH-conjugate as a result (Keen et al., 1976). In most cases the substrate is detoxified because the reactivity of the substrate with cellular macromolecules is decreased, but in a few cases the conjugate is more reactive than the substrate.

$$
\mathrm{GSH}+\mathrm{RX} \stackrel{\mathrm{GST}}{\longrightarrow} \mathrm{GSR}+\mathrm{HX}
$$

The formed glutathione conjugates are metabolized further by cleavage of the glutamate and glycine residues. The resulting cysteine $\mathrm{S}$-conjugate may be metabolized by $\mathrm{N}$-acetyltransferase to mercapturic acids, which are nontoxic and are excreted via the urine (Habig et al., 1974). The cysteine S-conjugates also can be substrates for the cysteine conjugate 
beta-lyase, which catalyzes either a beta-elimination or a transamination reaction to produce unstable thiols. These thiols rearrange to form potent acylating species that can covalently bind to cellular macromolecules, thereby producing cytotoxicity and mutagenicity (Lash, 1994).

The second function of GST is performing GPX activity towards lipid hydroperoxides, as described in part 4.3.1a (Prohaska, 1980). The third function of GSTs is intracellular transport of hydrophobic molecules, e.g., $\alpha$-tocopherol quinone, which binds to GST and may be transported to the site of metabolism or excreted in the bile (Arita et al., 1998). The fourth function of GSTs is reduction of the free concentration of toxic compounds through noncatalytic binding (Jakoby, 1978).

The cytosolic classes of GSTs are differentially expressed in various tissues, and various tissues may express different isoenzymes. The alpha and mu class isoenzymes are predominantly expressed in the liver and kidney and to a much lower and variable extent in other tissues (Awasthi et al., 1994). The most widely distributed isoenzyme is the pi class; it is the GST isoenzyme most abundantly present in many tissues. Glutathione S-transferase P occurs mostly in erythrocytes, placenta (Neefjes et al., 1999), and human skin, and is the isoenzyme expressed mostly in tumor cells (Guthenberg and Mannervik, 1981; Neefjes et al., 1999).

The genes for the mu and pi isoform of GST are polymorphic, and gene deletions for these genes occur quite often in human populations. The GST isoenzymes of the mu class are expressed in only $60 \%$ of the human population. In various epidemiological studies it has been reported that people homozygous for GST M1 deletions have an increased risk for the development of lung, bladder (Poppel van et al., 1992; Salagovic et al., 1998), and thyroid cancer (Morari et al., 2002). This is probably due to the fact that GST M and GST P are important in the detoxification reactions of polycyclic aromatic hydrocarbon (PAH) carcinogenic intermediates (Butkiewicz et al., 2000). Thus inhibition of the GST activity can increase the occurrence of different types of cancer because the harmful compounds cannot be detoxified. Also, the risk for other diseases e.g., cardiovascular diseases, will increase, because the detoxification of harmful products of lipid peroxidation (4-hydroxy2-nonenal), which are usually detoxified by GST (Ketterer, 1998), is also diminished. In tumor cells, however, GST may detoxify chemotherapeutics or its metabolites, decreasing the efficacy of the drug. In this way GST expression contributes to resistance against cytostatic drugs (Schultz et al., 1997). In this case inhibition of GST will be beneficial.

Another possible effect of inhibition of GST activity can be achieved by a conformational change in the molecule induced by the inhibitor. In the normal configuration GST can form a complex with Jun-JNK signal transduction proteins. In this way the C-jun terminal kinase is inhibited. After a conformational change of GST it cannot form a complex with Jun-JNK, enabling JNK phosphorylation of C-Jun, which is a stable and active transcription factor (Adler et al., 1999). Overexpression or hyperactivation of C-Jun can lead to uncontrolled proliferation and apoptosis.

A number of GST inhibitors have been described in literature but the only active in vivo inhibitors of GSTs are ethacrynic acid and a number of glutathione-derived structures (Iersel van et al., 1997). However, the glutathione-derived structures preferentially inhibit GST A (Ouwerkerk-Mahadevan and Mulder, 1998), whereas for inhibition of multiple drug resistance it is better to inhibit GST P, because GST P is the predominant form of GST present in human tumors. 
Glutathione $\mathrm{S}$-transferase $\mathrm{P}$ is preferentially inactivated by sulfhydryl group modifiers such as N-ethylmaleimide (NEM) (Shen et al., 1991). The cysteine residues at position 14, 47, 101 and 169 from the N-terminus are involved in this inhibition. The most reactive thiol group is Cys47 (Chang et al., 2001; Nishihira et al., 1992).

The three microsomal GSTs are members of the MAPEG proteins, which is a widespread superfamily. All the members of the family have a comparable size, ranging from 147 to 161 amino acids (Jakobsson et al., 1999; 2000). The amino acid sequence of MGST is not related to that of the cytosolic transferases, and the trimer of MGST consists of 154 amino acids per subunit (DeJong et al., 1988). Of the three microsomal GSTs the MGST 1 is most widely expressed. Up to $3 \%$ of the protein in liver microsomes consists of MGST 1 (Jakobsson et al., 2000), and $80 \%$ of it is located on the endoplasmic reticulum (Morgenstern et al., 1984).

Cytosolic and microsomal GST catalyze the same type of reactions, but there are also various differences between the cytosolic and microsomal GSTs. Firstly, the molecular weight of the subunits of MGST is much lower compared to the CGST subunits. Secondly, each subunit of MGST contains only one cysteine residue, whereas CGST subunits contain more than one cysteine group. Thirdly, CGST and MGST differ in substrate specificity; MGST has a very restricted substrate specificity compared to CGST (Morgenstern et al., 1982). A fourth difference between CGST and MGST is expressed when GST performs its peroxidase activity. While both MGST and CGST can reduce organic hydroperoxides by themselves, only MGST can reduce phospholipid hydroperoxides itself; CGST requires the participation of phospholipase $\mathrm{A}_{2}$ for the reduction of phospholipid hydroperoxides (Lundqvist et al., 1992; Sevanian et al., 1983). The fifth difference between MGST and CGST is a difference in modification. Activation of MGST is caused by modification of the sulfhydryl group with the thiol-modifying compound N-ethylmaleimide (NEM) (Haenen et al., 1987; Horbach et al., 1993; Ji and Bennett, 2002; Ji et al., 2002; Morgenstern et al., 1979), limited proteolysis, thiol-disulfide exchange, and ROS (e.g., $\mathrm{ONOO}^{-}, \mathrm{H}_{2} \mathrm{O}_{2}$, and $\mathrm{O}_{2}{ }^{--}$) (Aniya and Naito, 1993; Ji and Bennett, 2002). Activation of MGST occurs when SH-reactive electrophiles need to be detoxified (Haenen et al., 1988). Of the CGSTs it is known that they can be inactivated by NEM or other forms of ROS, e.g., $\mathrm{H}_{2} \mathrm{O}_{2}$ (Shen et al., 1991).

\subsection{1d. Multidrug Resistance-Associated Protein (MRP)}

The formed GSH conjugates, due to GST activity, have to be released from the intracellular compartment because these products give rise to a potent product inhibition of the GSTs (Burg and Mulder, 2002).

The GSH conjugates are eliminated from the cell to undergo further metabolism and to be excreted from the organism by energy-dependent efflux pumps. An example of such a pump is the glutathione S-conjugate transporter, also called the Multidrug Resistanceassociated Protein (MRP) (Hayes and McLellan, 1999; Suzuki and Sugiyama, 1998). The MRP is a multigene family of transport proteins that comprise at least six members. The most important proteins of this family are MRP1 and MRP2. They can transport drugs and glutathione conjugates out of the cell. Also, GSSG can be transported out of the cell by MRP. Although a poor substrate for the protein, GSH is required either as an activator or a cotransport substrate for the protein (Borst et al., 1999). 
Changing the expression or activity of MRP can have a variety of clinically important effects. Firstly, the excretion of endogenous compounds is impaired, resulting in different types of diseases e.g., hyperbilirubinemia. Secondly, the clearance of many clinically important drugs, including cancer chemotherapeutics, can be altered. Thirdly, cell redox status or response to oxidative stress can be altered since GSSG is a substrate for MRP (Gerk and Vore, 2002).

\subsubsection{Antioxidant Function}

The antioxidant role of GSH is the detoxification of electrophilic/oxidizing drugs and protection against lipid peroxidation. The thiol moiety of GSH is responsible for this antioxidant effect. The reduced form of the tripeptide is able to scavenge reactive species such as ROS, e.g., $\mathrm{OH}, \mathrm{HOCl}$, peroxynitrite, $\mathrm{RO}$, carbonyl-centered radicals, and ${ }^{1} \mathrm{O}_{2}$.

Also, GSH is able to bind $\mathrm{Cu}^{+}$through the cysteine thiol group, which leads to copper delivery to the apoprotein copper enzymes. By binding copper, GSH reduces the dangerous effects of free intracellular copper by decreasing potentially toxic reactions among metals and oxygen (Fenton reaction) (Filomeni et al., 2002).

\subsubsection{Pro-oxidant Activity}

When the gamma-glutamyl bond between Glu and Cys in GSH is hydrolyzed by GGT (part 4.2) cysteinyl-glycine is released. Most of the times this product is cleaved and the amino acids are used in GSH synthesis. However, the cysteinyl-glycine moiety can also have a pro-oxidant effect (Stark et al., 1993). The reactive thiol in the Cys-Gly can interact more efficiently than does GSH, with trace levels of iron ions present in the cell environment. This could cause the reduction of ferric iron $\left(\mathrm{Fe}^{3+}\right)$ to ferrous iron $\left(\mathrm{Fe}^{2+}\right)$, which is the start of a redox-cycling process, resulting in the production of ROS, i.e., superoxide anion in the first place, as well as thiyl radicals $\left(-S^{*}\right)$, and eventual stimulation of oxidative reactions such as lipid peroxidation. So, during the catabolism of GSH some pro-oxidant species can be formed, which can induce lipid peroxidation but can also react with critical targets in the intracellular signal transduction cascade.

\subsubsection{Nonantioxidant Function}

In cases of oxidative stress, GSSG can accumulate and form protein-glutathione mixed disulfides. The formation of these disulfides can result in impaired protein function. A significant number of proteins that have critical thiols and are involved in signaling functions, e.g., receptors, proteins involved in ubiquination, protein kinases, and some transcription factors, can be altered in their function. In this way GSSG acts as a nonspecific signaling molecule (Brigelius et al., 1983; Dickinson and Forman, 2002).

When transcription factors are altered, the capability of the protein to bind to DNA is inhibited. This results in inhibition of the effects of transcription factors and eventually to 
apoptosis (Filomeni et al., 2002). Therefore, it can be concluded that the GSH/GSSG redox pair can work as a sensor of oxidative stress.

\section{INTERPLAY BETWEEN VITAMIN E AND GLUTATHIONE (-DEPENDENT ENZYMES)}

\subsection{Interplay of Vitamin $E$ and GSH in Lipid Peroxidation}

Lipid peroxidation has been implicated as a major process in cellular damage. Glutathione is found to be a potent inhibitor of microsomal lipid peroxidation. Addition of GSH to rat liver microsomes, in which lipid peroxidation is induced, delayed the occurrence of lipid peroxidation (lag time). However, the maximal degree of lipid peroxidation [measured as thiobarbituric (TBA)-reactive material] is equal in incubation with or without GSH (Fig. 10) (Haenen and Bast, 1983).

This GSH-dependent protection proceeds via a heat-labile factor, probably an enzyme, because the protection is lost after heating of the microsomes (Haenen and Bast, 1983; Haenen et al., 1992; Scholz et al., 1989). The GSH-dependent protection is also absent in vitamin E depleted microsomes (Haenen et al., 1992; Reddy et al., 1982). It has been suggested that interplay exists between vitamin E radicals and GSH. Probably, the nonenzymatic reaction between GSH and the vitamin E radical is too slow due to the location of the vitamin E radical (membrane) and GSH (cytosol) in different compartments. It can be concluded that the protein involved has the characteristics of an enzyme. It has been suggested that this protein functions as a reductase. Although this reductase activity has never been demonstrated, the protein is often called free radical

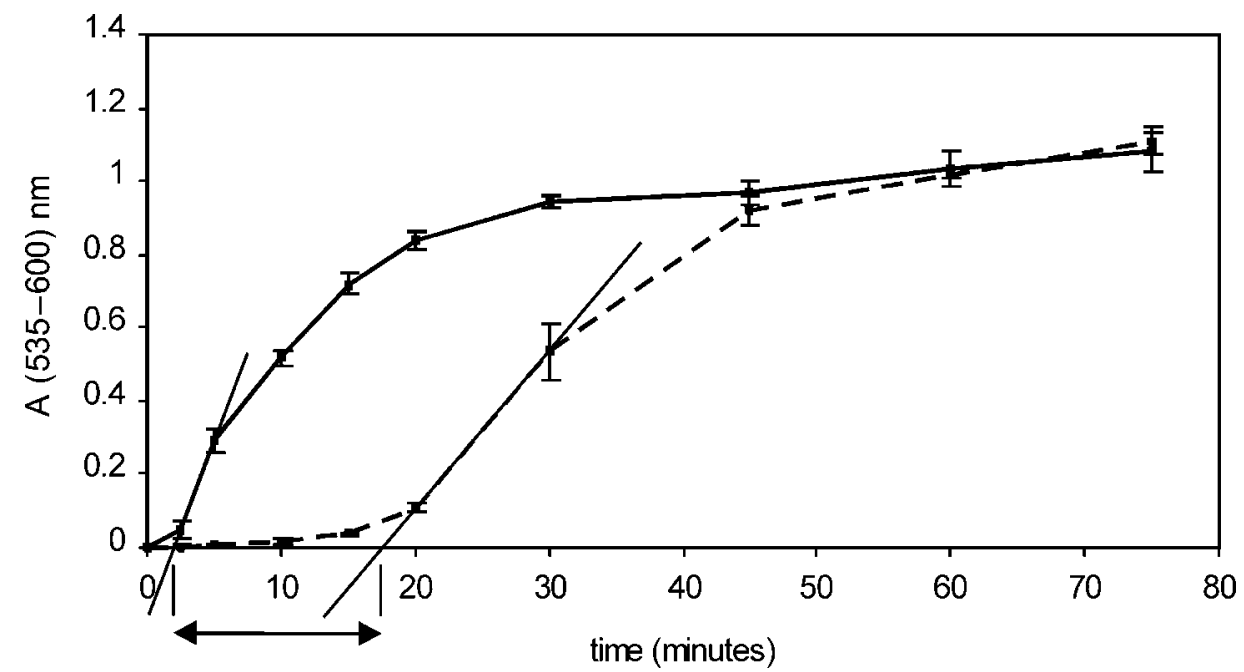

Figure 10. Influence of GSH $(1 \mathrm{mM})$ on the time-course of lipid peroxidation in control microsomes with (--) and without (-) addition of GSH. 
reductase (FRR) in literature. It regenerates $\alpha$-tocopherol from the $\alpha$-tocopherol radical (Graham et al., 1989; Haenen and Bast, 1983; Haenen et al., 1992) (Fig. 11). Additional studies indicate that the protein itself contains an essential and vulnerable thiol moiety and is selective for GSH as a cofactor. Glutathione disulfide and other disulfides e.g., cysteine, cystamine, mercaptoethanol, and dithiothreitol, had no effect on the reductase activity of the protein (Burk, 1983; Haenen et al., 1987; 1989; Scholz et al., 1997).

The maximal degree of lipid peroxidation in control microsomes and GSHsupplemented microsomes can be explained by the fact that FRR is vulnerable to oxidative stress. A product of lipid peroxidation, 4-hydroxy-2-nonenal, blocks the reductase function of FRR by alkylating the SH-moiety in the enzyme (Haenen et al., 1987). The free radical reductase is not specific for $\alpha$-tocopherol, but also acts with other compounds containing a free hydroxyl group, such as propofol (Aarts, 1995) or some flavonoids such as fisetin and naringenin (Acker van et al., 2000).

Not all the formed $\alpha$-tocopherol radicals are reduced to $\alpha$-tocopherol by GSH and FRR. The $\alpha$-tocopherol radicals that are not reduced can be oxidized further to $\alpha$-tocopherol quinone. In microsomes with a low $\alpha$-tocopherol level, $\alpha$-tocopherol quinone counteracts the reduction of $\alpha$-tocopherol radical to $\alpha$-tocopherol and in this way inhibits the GSH-dependent protection against lipid peroxidation. A possible explanation for this effect is that $\alpha$-tocopherol quinone competes with $\alpha$-tocopherol for binding to the FRR. The $\alpha$-tocopherol binding is superior to the binding of $\alpha$-tocopherol quinone to FRR (Haaften van et al., 2001a).

\subsection{Reduction of $\alpha$-Tocopherol Quinone by GSH}

It is demonstrated that $\alpha$-tocopherol quinone can be converted into $\alpha$-tocopherol in humans (Moore and Ingold, 1997). As described in the previous section (5.1), $\alpha$-tocopherol is regenerated from the $\alpha$-tocopherol radical by microsomal GSH-dependent free radical reductase. The assumption that $\alpha$-tocopherol quinone can also be reduced to $\alpha$-tocopherol by GSH was examined, both after direct interaction of $\alpha$-tocopherol quinone and GSH and in liver microsomal membranes. These membranes contain an important radical-producing system and a high content of $\alpha$-tocopherol, and once the lipophilic

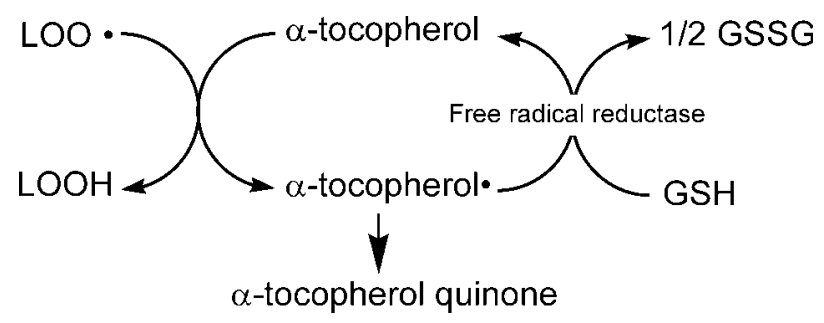

Figure 11. Interaction of $\alpha$-tocopherol and GSH in the protection against lipid peroxidation. $\alpha$-Tocopherol radicals are regenerated to $\alpha$-tocopherol by GSH. The reaction is catalyzed by a free radical reductase. Not all $\alpha$-tocopherol radicals will be reduced to $\alpha$-tocopherol. Some $\alpha$-tocopherol radicals will oxidize further to $\alpha$-tocopherol quinone. 
$\alpha$-tocopherol quinone is formed it is likely to be retained within the microsomal membrane. Moreover, the microsomes contain the GSH-dependent free radical reductase (Haenen and Bast, 1983; McCay et al., 1989). It was shown that no reduction of $\alpha$-tocopherol quinone by GSH to $\alpha$-tocopherol or $\alpha$-tocopherol hydroquinone occurred either directly in solution or in microsomes. So, the observed reduction of $\alpha$-tocopherol quinone to $\alpha$-tocopherol in humans is not due to direct interaction or to a GSH-dependent reaction with $\alpha$-tocopherol quinone in liver microsomes (Haaften van et al., 2001a). The mechanism of the reduction of $\alpha$-tocopherol quinone to $\alpha$-tocopherol is not known yet. It is assumed that it occurs by vitamin C (Wijesundara and Berger, 1994). But other investigators found that it would not happen by one of the natural reductants (Kohar et al., 1995) or even would not happen at all (Hughes and Tove, 1980).

\subsection{Effect of Vitamin E on GST Activity}

It is known that the pi form of GST is very susceptible to oxidative stress (Neefjes et al., 1999). So, it was assumed that antioxidants like vitamin E could have a protective effect on GST P.

Indeed, Chen and Shiau showed an increase in the activity of GST due to vitamin E treatment, which means that GSTs can be induced by vitamin E (Chen and Shiau, 1989). It is also shown that vitamin E can protect GST, because deficiency of vitamin E can lead to impairment of GST in microsomes (Tampo and Yonaha, 1990).

However, contrary to these two findings, some researchers have shown that rats fed a diet deficient in vitamin E and selenium have an increased GST activity (Mehlert and Diplock, 1985; Stone and Dratz, 1980). And it was also demonstrated that tocotrienol and tocopherol treatment of rat hepatocyte cultures significantly decreased GST activities at days 1-3 (Ong et al., 1993). In vitro studies with isolated human GST P1-1 isoenzyme also show that tocopherols, tocotrienols, $\alpha$-tocopherol derivatives, and $\alpha$-tocopherol quinone can inhibit the GST activity in a concentration dependent manner (Haaften van et al., 2001b,c; 2002). This inhibition is noncompetitive with respect to the substrates GSH and 1-chloro-2,4-dinitrobenzene (CDNB).

\section{CONCLUDING REMARKS}

As described in part 3.3, vitamin $\mathrm{E}$ has multiple functions. It has antioxidant activity, some pro-oxidant and also nonantioxidant effects. In all three groups of effects, anti-, pro-, and nonantioxidant, vitamin E can interplay with glutathione (-dependent enzymes) (part 5).

It is known that the various vitamers of vitamin $\mathrm{E}$ have comparable antioxidant activity. Some metabolites ( $\alpha$-tocopherolhydroquinone) have antioxidant activity, and vitamin $\mathrm{E}$ participates in an elaborate antioxidant network, which also involves GSH. Apparently the antioxidant/pro-oxidant effects of vitamin E are not specific. It is also possible that vitamin $\mathrm{E}$ or its metabolites display pro-oxidant activity, depending on the oxidation state of the cell. The nonantioxidant functions of vitamin $\mathrm{E}$ are more specific because the different vitamers can perform different or even antagonistic activities. 
For instance, $\alpha$-tocopherol inhibits PKC and $\beta$-tocopherol antagonizes this; tocotrienols inhibit HMG-CoA reductase and tocopherols do not. However, multiple vitamers of vitamin $\mathrm{E}$ can inhibit GST activity.

To test the antioxidant effects of vitamin E some human clinical intervention studies have been performed. However, as already described in part 3.3.3 these studies do not lead to a unequivocal conclusion. The nonantioxidant functions of vitamin $\mathrm{E}$ have not been investigated in clinical intervention studies. Which function of vitamin $\mathrm{E}$ is more important — the antioxidant or the nonantioxidant function —is a question that should be raised.

In 1967 it was already proposed by Olson and Carpenter that $\alpha$-tocopherol functions, in cooperation with a regulatory gene, to control excessive synthesis of catabolic enzymes. Vitamin E deficiency reduces the serum creatine phosphokinase content by reduction of its synthesis (Olson and Carpenter, 1967). More recently, Azzi and Stocker have also

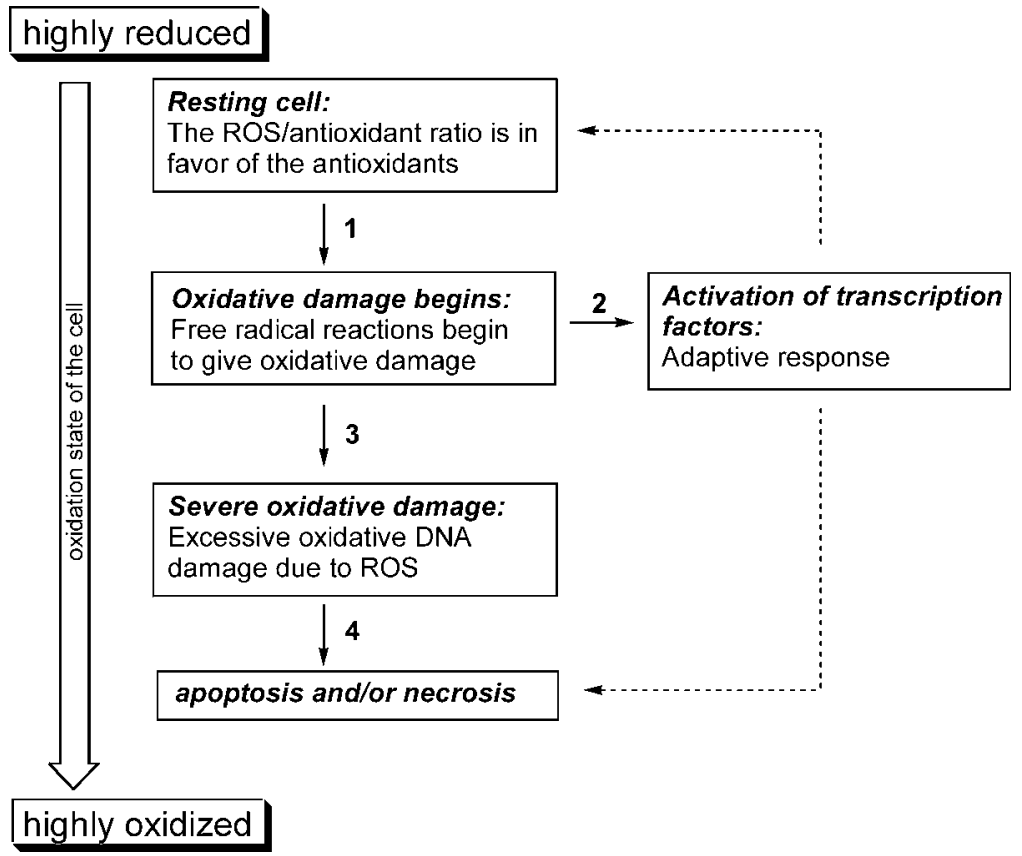

Figure 12. The paradoxical functions of vitamin $\mathrm{E}$ and glutathione. In a reduced state a functional cellular antioxidant network with vitamin $\mathrm{E}$ and glutathione is active. To combat oxidative damage these compounds act together with FRR to prevent the process of lipid peroxidation. (1) Changing the ratio of ROS/antioxidants towards ROS will induce oxidative damage. Supplementation of vitamin E or GSH will protect the cell. (2) During adaptation to oxidative stress the nonantioxidant functions of vitamin $\mathrm{E}$ and GSH take place. The consequences of these nonantioxidant functions can be opposite. (3) When the antioxidant functions are not adequate, severe oxidative damage takes place in the cell. Vitamin E and GSH can display a pro-oxidant action by accelerating oxidative damage by reacting with traces of transition metal ions. Also $\alpha$-tocopherol quinone can perform prooxidant effects in the process of lipid peroxidation. (4) Eventually this will lead to apoptosis and/or necrosis. 
reported that the antioxidant effect of vitamin $\mathrm{E}$ is not the primary action of vitamin $\mathrm{E}$. Diverse cellular functions of vitamin E, unrelated to their antioxidant activity, are known (part 3.3.3). For these functions vitamin E would act as sensor for oxidative stress due to its oxidizability which means that it triggers the cellular response toward oxidative stress (Azzi and Stocker, 2000; Stocker et al., 1999). Also, some gene-regulatory functions of $\alpha-$ tocopherol have been displayed (Azzi et al., 2002a,b; Ricciarelli et al., 2002), e.g., upregulation of $\alpha$-tropomyosin expression by $\alpha$-tocopherol, and not by $\beta$-tocopherol. Probably this is indirectly elicited via inhibition of PKC activity due to $\alpha$-tocopherol (Aratri et al., 1999). Overexpression of tropomyosin in vascular smooth muscle cells diminishes the blood pressure via decreasing the contractility or the smooth muscle cells.

Despite the diverse and in part potentially negative effects of vitamin E, it is used in many products, including cosmetic products and food supplements. Probably it would be better to know more about the status, e.g., oxidant status, of the patient before using vitamin E as a supplement (Halliwell, 2000). As indicated in Fig. 12, vitamin E and GSH can perform different actions during the diverse oxidation states of the cell. At the beginning of oxidative damage it is useful to have more vitamin $\mathrm{E}$ and GSH, but at severe oxidative damage these compounds can display pro-oxidant activity.

\section{REFERENCES}

Aarts, L., Hee van der, R., Dekker, I., Jong de, J., Langemeijer, H., Bast, A. (1995). The widely used anesthetic agent propofol can replace alpha-tocopherol as an antioxidant. Fed. Eur. Biochem. Soc. 357:83-85.

Acker van, F. A. A., Schouten, O., Haenen, G. R. M. M., Vijgh van der, W. J. F., Bast, A. (2000). Flavonoids can replace alpha-tocopherol as an antioxant. Fed. Eur. Biochem. Soc. Lett. 473:145-148.

Adler, V., Yin, Z., Fuchs, S. Y., Benezra, M., Rosario, L., Tew, K. D., Pincus, M. R., Sardana, M., Henderson, C. J., Wolf, C. R., Davis, R. J., Ronai, Z. (1999). Regulation of JNK signaling by GSTp. EMBO J. 18:1321-1334.

Aniya, Y., Naito, A. (1993). Oxidative stress-induced activation of microsomal glutathione S-transferase in isolated rat liver. Biochem. Pharmacol. 45:37-42.

Aratri, E., Spycher, S., Breyer, I., Azzi, A. (1999). Modulation of alpha-tropomyosin expression by alpha-tocopherol in rat vascular smooth muscle cells. Fed. Eur. Biochem. Soc. Lett. 447:91-94.

Arita, M., Sato, Y., Arai, H., Inoue, K. (1998). Binding of alpha-tocopherylquinone, an oxidized form of alpha-tocopherol, to glutathione-S-transferase in the liver cytosol. Fed. Eur. Biochem. Soc. Lett. 436:424-426.

Arrigo, A. P. (1999). Gene expression and the thiol redox state. Free Radic. Biol. Med. 27:936-944.

Awasthi, Y. C., Sharma, R., Singhal, S. S. (1994). Human glutathione S-transferases. Int. J. Biochem. 26:295-308.

Azzi, A., Stocker, A. (2000). Vitamin E: non-antioxidant roles. Prog. Lipid Res. 39:231-255.

Azzi, A., Boscoboinik, D., Chatelain, E., Ozer, N. K., Stauble, B. (1993). d-alphatocopherol control of cell proliferation. Mol. Asp. Med. 14:265-271. 
Azzi, A., Boscoboinik, D., Clement, S., Ozer, N. K., Ricciarelli, R., Stocker, A., Tasinato, A., Sirikci, O. (1997). Signalling functions of alpha-tocopherol in smooth muscle cells. Int. J. Vitam. Nutr. Res. 67:343-349.

Azzi, A., Boscoboinik, D., Clement, S., Ozer, N., Ricciarelli, R., Stocker, A. (1999). Vitamin E mediated response of smooth muscle cell to oxidant stress. Diabetes Res. Clin. Pract. 45:191-198.

Azzi, A., Breyer, I., Feher, M., Ricciarelli, R., Stocker, A., Zimmer, S., Zingg, J. (2001). Nonantioxidant functions of alpha-tocopherol in smooth muscle cells. J. Nutr. 131:378S-381S.

Azzi, A., Gysin, R., Ricciarelli, R., Villacorta, L., Visarius, T., Zingg, J.-M. (2002a). Regulation of gene and protein expression by vitamin E. Free Radic. Res. 36:30-35.

Azzi, A., Ricciarelli, R., Zingg, J. M. (2002b). Non-antioxidant molecular functions of alpha-tocopherol (vitamin E). Fed. Eur. Biochem. Soc. Lett. 519:8-10.

Bast, A., Haenen, G. R. M. M. (1991). Zin en onzin van antioxidantia. Pharm. Weekbl. 126:600-605.

Bast, A., Haenen, G. R., Doelman, C. J. (1991). Oxidants and antioxidants: state of the art. Am. J. Med. 91:2S-13S.

Bauernfeind, J. C. (1977). The tocopherol content of food and influencing factors. Crit. Rev. Food Sci. Nutr. 8:337-382.

Bindoli, A., Valente, M., Cavallini, L. (1985). Inhibition of lipid peroxidation by alphatocopherolquinone and alpha-tocopherolhydroquinone. Biochem. Int. 10:753-761.

Birringer, M., Drogan, D., Bregelius-Flohe, R. (2001). Tocopherols are metabolized in HepG 2 cells by side chain $\omega$-oxidation and consecutive $\beta$-oxidation. Free Radic. Biol. Med. 31:226-232.

Birringer, M., Pfluger, P., Kluth, D., Landes, N., Brigelius Flohe, R. (2002). Identities and differences in the metabolism of tocotrienols and tocopherols in HepG2 cells. J. Nutr. 132:3113-3118.

Bjorneboe, A., Bjorneboe, G. E. A., Drevon, C. A. (1990). Absorption, transport and distribution of vitamin E. J. Nutr. 120:233-242.

Black, S. M., Wolf, C. R. (1991). The role of glutathione-dependent enzymes in drug resistance. Pharmacol. Ther. 51:139-154.

Blatt, D. H., Leonard, S., Traber, M. (2001). Vitamin E kinetics and the function of tocopherol regulatory proteins. Nutrition 17.

Board, P. G., Baker, R. T., Chelvanayagam, G., Jermiin, L. S. (1997). Zeta, a novel class of glutathione transferases in a range of species from plants to humans. Biochem. J. 328:929-935.

Board, P. G., Coggan, M., Chelvanayagam, G., Easteal, S., Jermiin, L. S., Schulte, G. K., Danley, D. E., Hoth, L. R., Griffor, M. C., Kamath, A. V., Rosner, M. H., Chrunyk, B. A., Perregaux, D. E., Gabel, C. A., Geoghegan, K. F., Pandit, J. (2000). Identification, characterization, and crystal structure of the Omega class glutathione transferases. J. Biol. Chem. 275:24798-24806.

Borst, P., Evers, R., Kool, M., Wijnholds, J. (1999). The multidrug resistance protein family. Biochim. Biophys. Acta 1461:347-357.

Brigelius, R., Muckel, C., Akerboom, T. P., Sies, H. (1983). Identification and quantitation of glutathione in hepatic protein mixed disulfides and its relationship to glutathione disulfide. Biochem. Pharmacol. 32:2529-2534. 
Brigelius Flohe, R., Traber, M. G. (1999). Vitamin E: function and metabolism. FASEB J. 13:1145-1155.

Brigelius Flohe, R., Kelly, F. J., Salonen, J. T., Neuzil, J., Zingg, J. M., Azzi, A. (2002). The European perspective on vitamin E: current knowledge and future research. Am. J. Clin. Nutr. 76:703-716.

Burg, D., Mulder, G. J. (2002). Glutathione conjugates and their synthetic derivatives as inhibitors of glutathione-dependent enzymes involved in cancer and drug resistance. Drug Metab. Rev. 34:821-863.

Burk, R. F. (1983). Glutathione-dependent protection by rat liver microsomal protein against lipid peroxidation. Biochem. Biophys. Acta 757:21-28.

Burton, G. W., Traber, M. G. (1990). Vitamin E: antioxidant activity, biokinetics, and bioavailability. Annu. Rev. Nutr. 10:357-382.

Butkiewicz, D., Grzybowska, E., Phillips, D. H., Hemminki, K., Chorazy, M. (2000). Polymorphisms of the GSTP1 and GSTM1 genes and PAH-DNA adducts in human mononuclear white blood cells. Environ. Mol. Mutagen. 35:99-105.

Chan, A. C. (1998). Vitamin E and atherosclerosis. J. Nutr. 128:1593-1596.

Chang, M., Shin, Y. G., van Breemen, R. B., Blond, S. Y., Bolton, J. L. (2001). Structural and functional consequences of inactivation of human glutathione S-transferase P1-1 mediated by the catechol metabolite of equine estrogens, 4-hydroxyequilenin. Biochemistry 40:4811-4820.

Chaudiere, J., Ferrari Iliou, R. (1999). Intracellular antioxidants: from chemical to biochemical mechanisms. Food Chem. Toxicol. 37:949-962.

Cheeseman, K. H., Holley, A. E., Kelly, F. J., Wasil, M., Hughes, L., Burton, G. (1995). Biokinetics in humans of RRR-alpha-tocopherol: the free phenol, acetate ester, and succinate ester forms of vitamin E. Free Radic. Biol. Med. 19:591-598.

Chen, L. H., Shiau, C. C. (1989). Induction of glutathione-S-transferase activity by antioxidants in hepatocyte culture. Anticancer Res. 9:1069-1072.

Chow, C. K. (1983). On the formation and measurement of alpha-tocopherolquinone and alpha-tocopherolhydroquinone in rat tissues. Nutr. Rev. 41:98-99.

Clough, R. L., Yee, B. G., Foote, C. S. (1979). Chemistry of singlet oxygen. The unstable primary product of tocopherol photooxidation. J. Am. Soc. 101:683-686.

Cooney, R. V., Harwood, P. J., Franke, A. A., Narala, K., Sundstrom, A., Berggren, P., Mordan, L. J. (1995). Products of gamma-tocopherol reaction with NO2 and their formation in rat insulinoma (RINm5F) cells. Free Radic. Biol. Med. 19:259-269.

Cornwell, D. G., Huttner, J. J., Milo, G. E., Panganamala, R. V., Sharma, H. M., Geer, J. C. (1979). Polyunsaturated fatty acids, vitamin E, and the proliferation of aortic smooth muscle cells. Lipids 14:194-207.

Cornwell, D. G., Williams, M. V., Wani, A. A., Wani, G., Shen, E., Jones, K. H. (2002). Mutagenicity of tocopheryl quinones: evolutionary advantage of selective accumulation of dietary alpha-tocopherol. Nutr. Cancer 43:111-118.

DeJong, J. L., Morgenstern, R., Jornvall, H., DePierre, J. W., Tu, C. P. (1988). Gene expression of rat and human microsomal glutathione S-transferases. J. Biol. Chem. 263:8430-8436.

Deneke, S. M., Fanburg, B. L. (1989). Regulation of cellular glutathione. Am. J. Physiol. 257:L163-L173. 
Dickinson, D., Forman, H. (2002). Cellular glutathione and thiols metabolism. Biochem. Pharmacol. 64:1019.

Dinkova-Kostova, D. T., Talalay, P. (2000). Persuasive evidence that quinone reductase type 1 (DT diaphorase) protects cells against the toxicity of electrophiles and reactive forms of oxygen. Free Radic. Biol. Med. 29:231-240.

d'Ischia, M., Novellino, L. (1996). Nitric oxide-induced oxidation of alpha-tocopherol. Bioorg. Med. Chem. 4:1747-1753.

Douglas, K. T. (1987). Mechanism of action of glutathione-dependent enzymes. Adv. Enzymol. Relat. Areas Mol. Biol. 59:103-167.

Drevon, C. A. (1991). Absorption, transport and metabolism of vitamin E. Free Radic. Res. Commun. 14:229-246.

Eaton, D. L., Bammler, T. K. (1999). Concise review of the glutathione S-transferases and their significance to toxicology. Toxicol. Sci. 49:156-164.

Eder, K., Flader, D., Hirche, F., Brandsch, C. (2002). Excess dietary vitamin E lowers the activities of antioxidative enzymes in erythrocytes of rats fed salmon oil. J. Nutr. 132:3400-3404.

Evans, H. M., Bishop, K. S. (1922). On the relationship between fertility and nutrition. J. Metab. Sci. 1:319-356.

Evans, P., Halliwell, B. (2001). Micronutrients: oxidant/antioxidant status. Br. J. Nutr. 85(Suppl. 2):S67-S74.

Evans, H. M., Emerson, O. H., Emerson, G. A. (1936). The isolation from wheat-germ oil of an alcohol, alpha-tocopherol, having the properties of vitamin E. J. Biol. Chem. 113:319.

Fernholz, E. (1938). On the constitution of alpha-tocopherol. J. Am. Chem. Soc. 60:700-705.

Filomeni, G., Rotilio, G., Ciriolo, M. (2002). Cell signaling and the glutathione redox system. Biochem. Pharmacol. 64:1057.

Flohe, L. (1988). Glutathione peroxidase. Basic Life Sci. 49:663-668.

Gerk, P. M., Vore, M. (2002). Regulation of expression of the multidrug resistanceassociated protein 2 (MRP2) and its role in drug disposition. J. Pharmacol. Exp. Ther. 302:407-415.

Giamvala, D. H., Church, D. F., Pryor, W. A. (1986). Kinetics of ozonation. Reactions of ozone with alpha-tocopherol and oleate and linoleate esters in carbon tetrachloride and in aqueous micellar solvents. J. Am. Chem. Soc. 108:6646-6651.

Girotti, A. W. (1985). Mechanisms of lipid peroxidation. J. Free Radic. Biol. Med. 1:87-95.

Graham, K. S., Reddy, C. C., Scholz, R. W. (1989). Reduced glutathione effects on alphatocopherol concentration of rat liver microsomes undergoing NADPH-dependent lipid peroxidation. Lipids 24:909-914.

Griffith, O. W., Meister, A. (1979). Glutathione: interorgan translocation, turnover, and metabolism. Proc. Natl Acad. Sci. USA 76:5606-5610.

Guthenberg, C., Mannervik, B. (1981). Glutathione S-transferase (transferase pi) from human placenta is identical or closely related to glutathione S-transferase (transferase rho) from erythrocytes. Biochim. Biophys. Acta 661:255-260.

Haaften van, R. I. M., Evelo, C. T., Haenen, G. R. M. M., Bast, A. (2001a). No reduction of alpha-tocopherol quinone by glutathione in rat liver microsomes. Biochem. Pharmacol. 61:715-719. 
Haaften van, R. I. M., Evelo, C. T. A., Penders, J., Eijnwachter, M. P. F., Haenen, G. R. M. M., Bast, A. (2001b). Inhibition of human glutathione S-transferase P1-1 by tocopherols and alpha-tocopherol derivatives. Biochim. Biophys. Acta 1548:23-28.

Haaften van, R. I. M., Evelo, C. T. A., Haenen, G. R. M. M., Bast, A. (2001c). Alphatocopherol inhibits human glutathione S-transferase pi. Biochem. Biophys. Res. Commun. 280:631-633.

Haaften van, R. I. M., Haenen, G. R. M. M., Evelo, C. T. A., Bast, A. (2002). Tocotrienols inhibit human glutathione S-transferase P1-1. Int. Union Biochem. Mol. Biol. Life 54:81-84.

Habig, W. H., Pabst, M. J., Jakoby, W. B. (1974). Glutathione S-transferases. The first enzymatic step in mercapturic acid formation. J. Biol. Chem. 249:7130-7139.

Haenen, G. R. M. M., Bast, A. (1983). Protection against lipid peroxidation by a microsomal glutathione-dependent labile factor. Fed. Eur. Biochem. Soc. 159:24-28.

Haenen, G. R. M. M., Tai Tin Tsoi, J. N. L., Vermeulen, N. P. E., Timmerman, H., Bast, A. (1987). 4-Hydroxy-2,3-trans-nonenal stimulates microsomal lipid peroxidation by reducing the glutathione-dependent protection. Arch. Biochem. Biophys. 259:449-456.

Haenen, G. R., Vermeulen, N. P., Tai Tin Tsoi, J. N., Ragetli, H. M., Timmerman, H., Blast, A. (1988). Activation of the microsomal glutathione-S-transferase and reduction of the glutathione dependent protection against lipid peroxidation by acrolein. Biochem. Pharmacol. 37:1933-1938.

Haenen, G. R., Vermeulen, N. P., Timmerman, H., Bast, A. (1989). Effect of thiols on lipid peroxidation in rat liver microsomes. Chem.-Biol. Interact. 71:201-212.

Haenen, G. R. M. M., Bastiaans, H. M. M., Bast, A. (1992). Mechanism of the glutathionedependent protection against microsomal lipid peroxidation. In: Yagi, K., Kondo, M., Niki, E., Yoshikawa, T., eds. Oxygen Radicals. Amsterdam: Exerpta Medica, pp. 731-736.

Halliwell, B. (1995). How to characterize an antioxidant: an update. Biochem. Soc. Symp. 61:73-101.

Halliwell, B. (2000). The antioxidant paradox. Lancet 355:1179-1180.

Halliwell, B., Gutteridge, J. M. C. (1999). Antioxidant defences. In: Halliwell, B., Gutteridge, J. M. C., eds. Free Radicals in Biology and Medicine. New York: Oxford University Press, Inc., pp. 105-245.

Hayashi, T., Kanetoshi, A., Nakamura, M., Tamura, M., Shirahama, H. (1992). Reduction of alpha-tocopherolquinone to alpha-tocopherolhydroquinone in rat hepatocytes. Biochem. Pharmacol. 44:489-493.

Hayes, J. D., McLellan, L. I. (1999). Glutathione and glutathione-dependent enzymes represent a co-ordinately regulated defence against oxidative stress. Free Radic. Res. 31:273-300.

Hayes, J. D., Pulford, D. J. (1995). The glutathione S-transferase supergene family: regulation of GST and the contribution of the isoenzymes to cancer chemoprotection and drug resistance. Crit. Rev. Biochem. Mol. Biol. 30:445-600.

Hogg, N. H., Joseph, J., Kalyanaraman, B. (1994). The oxidation of alpha-tocopherol and trolox by peroxynitrite. Arch. Biochem. Biophys. 314:153-158.

Horbach, M. E., Sies, H., Akerboom, T. P. (1993). Identification of a hepatic plasma membrane glutathione S-transferase activated by $\mathrm{N}$-ethylmaleimide. Biochim. Biophys. Acta 1148:61-66. 
Hosomi, A., Arita, M., Sato, Y., Kiyose, C., Ueda, T., Igarashi, O., Arai, H., Inoue, K. (1997). Affinity for alpha-tocopherol transfer protein as a determinant of the biological activities of vitamin E analogs. Fed. Eur. Biochem. Soc. 409:105-108.

Houte van, H., De Hoffmann, E., Van Veldhoven, P. P., Mannaerts, G. P., Carchon, H., Baes, M. I., Declercq, P. E. (2001). Oxidative catabolism of alpha-tocopherol in rat liver microsomes. Lipids 36:367-372.

Hughes, P. E., Tove, S. B. (1980). Synthesis of alpha-tocopherolquinone by the rat and its reduction by mitochondria. J. Biol. Chem. 255:7095-7097.

Iersel van, M. L., Ploemen, J. P., Lo-Bello, M., Federici, G., van-Bladeren, P. J. (1997). Interactions of alpha, beta-unsaturated aldehydes and ketones with human glutathione S-transferase P1-1. Chem.-Biol. Interact. 108:67-78.

Jakobsson, P. J., Morgenstern, R., Mancini, J., Ford Hutchinson, A., Persson, B. (1999). Common structural features of MAPEG - a widespread superfamily of membrane associated proteins with highly divergent functions in eicosanoid and glutathione metabolism. Protein Sci. 8:689-692.

Jakobsson, P. J., Morgenstern, R., Mancini, J., Ford Hutchinson, A., Persson, B. (2000). Membrane-associated proteins in eicosanoid and glutathione metabolism (MAPEG). A widespread protein superfamily. Am. J. Respir. Crit. Care Med. 161:S20-S24.

Jakoby, W. B. (1978). The glutathione S-transferases: a group of multifunctional detoxification proteins. Adv. Enzymol. Relat. Areas Mol. Biol. 46:383-414.

Ji, Y., Bennett, B. M. (2002). Activation of microsomal glutathione S-transferase by peroxynitrite. Mol. Pharmacol. 63:136-146.

Ji, Y., Toader, V., Bennett, B. M. (2002). Regulation of microsomal and cytosolic glutathione S-transferase activities by S-nitrosylation. Biochem. Pharmacol. 63:1397-1404.

Jiang, Q., Elson Schwab, I., Courtemanche, C., Ames, B. N. (2000). Gamma-tocopherol and its major metabolite, in contrast to alpha-tocopherol, inhibit cyclooxygenase activity in macrophages and epithelial cells. Proc. Natl Acad. Sci. USA 97:11494-11499.

Jones, K. H., Liu, J. J., Roehm, J. S., Eckel, J. J., Eckel, T. T., Stickrath, C. R., Triola, C. A., Jiang, Z., Bartoli, G. M., Cornwell, D. G. (2002). Gamma-tocopheryl quinone stimulates apoptosis in drug-sensitive and multidrug-resistant cancer cells. Lipids $37: 173-184$.

Kamal-Eldin, A., Appelqvist, L. A. (1996). The chemistry and antioxidant properties of tocopherols and tocotrienols. Lipids 31:671-701.

Kantoci, D., Wechter, W. J., Murray, D. J., Dewind, S. A., Borchardt, D., Khan, S. I. (1997). Endogenous natriuretic factors 6: the stereochemistry of a natriuretic $\gamma$-tocopherol metabolite LLU- $\alpha$. J. Pharmacol. Exp. Ther. 282:648-656.

Kappus, H., Diplock, A. T. (1992). Tolerance and safety of vitamin E: a toxicological position report. Free Radic. Biol. Med. 13:55-74.

Keen, J. H., Habig, W. H., Jakoby, W. B. (1976). Mechanism for the several activities of the glutathione S-transferases. J. Biol. Chem. 251:6183-6188.

Ketterer, B. (1998). Glutathione S-transferases and prevention of cellular free radical damage. Free Radic. Res. 28:647-658.

Khor, H. T., Ng, T. T. (2000). Effects of administration of alpha-tocopherol and tocotrienols on serum lipids and liver HMG CoA reductase activity. Int. J. Food Sci. Nutr. 51:S3-S11. 
Kohar, I., Baca, M., Suarna, C., Stocker, R., Southwell-Keely, P. T. (1995). Is alphatocopherol a reservoir for alpha-tocopheryl hydroquinone? Free Radic. Biol. Med. 19:197-207.

Kondo, T., Yoshida, K., Urata, Y., Goto, S., Gasa, S., Taniguchi, N. (1993). Gamma-glutamylcysteine synthetase and active transport of glutathione S-conjugate are responsive to heat shock in K562 erythroid cells. J. Biol. Chem. 268:20366-20372.

Krendel, D. A., Gilchrist, J. M., Johnson, A. O., Bossen, E. H. (1987). Isolated deficiency of vitamin E with progressive neurologic deterioration. Neurology 37:538-540.

Laplante, P., Vanasse, M., Michaud, J., Geoffroy, G., Brochu, P. (1984). A progressive neurological syndrome associated with an isolated vitamin E deficiency. Can. J. Neurol. Sci. 11:561-564.

Larnaout, A., Belal, S., Zouari, M., Fki, M., Ben Hamida, C., Goebel, H. H., Ben Hamida, M., Hentati, F. (1997). Friedreich's ataxia with isolated vitamin E deficiency: a neuropathological study of a Tunisian patient. Acta Neuropathol. 93:633-637.

Lash, L. H. (1994). Role of renal metabolism in risk to toxic chemicals. Environ. Health Perspect. 102(Suppl. 11):75-79.

Liebler, D. C. (1993). The role of metabolism in the antioxidant function of vitamin E. Crit. Rev. Toxicol. 23:147-169.

Liebler, D. C. (1998). Antioxidant chemistry of alpha-tocopherol in biological systems. Roles of redox cycles and metabolism. In: Quinn, P.S., Kagan, V.E., eds. Sub-cellular Biochemistry: Reviews and Essays with the Structure, Function, Genetics, Biogenesis and Evolution of Sub-cellular Components. Vol. 30. New York: Plenum Press, pp. 301-317.

Liebler, D. C., Burr, J. A. (2000). Antioxidant reactions of alpha-tocopherolhydroquinone. Lipids 35:1045-1047.

Liebler, D. C., Matsumoto, S., Iitaka, Y., Matsuo, M. (1993). Reactions of vitamin E and its model compound 2,2,5,7,8-pentamethylchroman-6-ol with ozone. Chem. Res. Toxicol. 6:69-74.

Lindsey, J. A., Zhang, H. F., Kaseki, H., Morisaki, N., Sato, T., Cornwell, D. G. (1985). Fatty acid metabolism and cell proliferation. VII. Antioxidant effects of tocopherols and their quinones. Lipids 20:151-157.

Lundqvist, G., Yucel Lindberg, T., Morgenstern, R. (1992). The oligomeric structure of rat liver microsomal glutathione transferase studied by chemical cross-linking. Biochim. Biophys. Acta 1159:103-108.

Maiorino, M., Zamburlini, A., Roveri, A., Ursini, F. (1993). Prooxidant role of vitamin E in copper induced lipid peroxidation. Fed. Eur. Biochem. Soc. 330:174-176.

Mannervik, B. (1985). The isoenzymes of glutathione transferase. Adv. Enzymol. Relat. Areas Mol. Biol. 57:357-417.

Mannervik, B., Awasthi, Y. C., Board, P. G., Hayes, J. D., Di-Ilio, C., Ketterer, B., Listowsky, I., Morgenstern, R., Muramatsu, M., Pearson, W. R. (1992). Nomenclature for human glutathione transferases [letter]. Biochem. J. 282:305-306.

Manson, J. E., Bassuk, S. S., Stampfer, M. J. (2003). Does vitamin E supplementation prevent cardiovascular events? J. Women's Health 12:123-136.

Marchioli, R. (1999). Dietary supplementation with $n-3$ polyunsaturated fatty acids and vitamin E after myocardial infarction: results of the GISSI-Prevenzione trial. Lancet 354:447-455. 
Mason, K. E. (1933). Differences in testis injury and repair after vitamin A-deficiency, vitamin E-deficiency, and inanition. Am. J. Anat. 52:153-227.

Matsuo, M., Matsumoto, S. (1987). Oxygenations of vitamin E (alpha-tocopherol) and its model compound 2,2,5,7,8-pentamethylchroman-6-ol in the presence of the superoxide radical solubilized in aprotic solvents: unique epoxidations and recyclizations. J. Org. Chem. 52:3514-3520.

McCay, P. B., Gibson, D. D., Fong, K., Hornbrook, K. R. (1976). Effect of glutathione peroxidase activity on lipid peroxidation in biological membranes. Biochim. Biophys. Acta 431:459-468.

McCay, P. B., Brueggemann, G., Lai, E. K., Powell, S. R. (1989). Evidence that alphatocopherol functions cyclically to quench free radicals in hepatic microsomes. Ann. NY Acad. Sci. 570:32-45.

Meagher, E. A. (2003). Treatment of atherosclerosis in the new millennium: is there a role for vitamin E? Prev. Cardiol. 6:85-90.

Mehlert, A., Diplock, A. T. (1985). The glutathione S-transferases in selenium and vitamin E deficiency. Biochem. J. 227:823-831.

Meydani, M. (1995). Vitamin E. Lancet 345:170-175.

Mills, G. C. (1957). Hemoglobin catabolism I. Glutathione peroxidase, an erythrocyte enzyme which protects hemoglobin from oxidative breakdown. J. Biol. Chem. 229:189-197.

Minotti, G., Aust, S. D. (1992). Redox cycling of iron and lipid peroxidation. Lipids 27:219-226.

Moellering, D., Mc Andrew, J., Patel, R. P., Forman, H. J., Mulcahy, R. T., Jo, H., Darley Usmar, V. M. (1999). The induction of GSH synthesis by nanomolar concentrations of NO in endothelial cells: a role for gamma-glutamylcysteine synthetase and gammaglutamyl transpeptidase. Fed. Eur. Biochem. Soc. Lett. 448:292-296.

Moore, A. N. J., Ingold, K. U. (1997). Alpha-tocopherol quinone is converted into vitamin $\mathrm{E}$ in man. Free Radic. Biol. Med. 22:931-934.

Morari, E. C., Leite, J. L., Granja, F., Da-Assumpcao, L. V., Ward, L. S. (2002). The null genotype of glutathione S-transferase M1 and T1 locus increases the risk for thyroid cancer. Cancer Epidemiol. Biomark. Prev. 11:1485-1488.

Morgenstern, R., DePierre, J. W., Ernster, L. (1979). Activation of microsomal glutathione S-transferase activity by sulfhydryl reagents. Biochem. Biophys. Res. Commun. $87: 657-663$.

Morgenstern, R., Guthenberg, C., Depierre, J. W. (1982). Microsomal glutathione $\mathrm{S}$-transferase. Purification, initial characterization and demonstration that it is not identical to the cytosolic glutathione S-transferases A, B and C. Eur. J. Biochem. 128:243-248.

Morgenstern, R., Lundqvist, G., Andersson, G., Balk, L., DePierre, J. W. (1984). The distribution of microsomal glutathione transferase among different organelles, different organs, and different organisms. Biochem. Pharmacol. 33:3609-3614.

Mulcahy, R. T., Gipp, J. J. (1995). Identification of a putative antioxidant response element in the $5^{\prime}$-flanking region of the human gamma-glutamylcysteine synthetase heavy subunit gene. Biochem. Biophys. Res. Commun. 209:227-233.

Napoli, C., Leccese, M., Palumbo, G., Nigris, F. D., Chiariello, P., Zuliani, P., Somma, P., Di Loreto, M., De Matteis, C., Cacciatore, F., Abete, P., Liguori, A., Chiariello, M., 
D’Armiento, F. P. (1998). Effects of vitamin E and HMG-CoA reductase inhibition on cholesteryl ester transfer protein and lecithin-cholesterol acyltransferase in hypercholesterolemia. Coron. Artery Dis. 9:257-264.

Neefjes, V. M., Evelo, C. T., Baars, L. G., Blanco, C. E. (1999). Erythrocyte glutathione S transferase as a marker of oxidative stress at birth. Arch. Dis. Childhood 81:F130-F133.

Nishihira, J., Ishibashi, T., Sakai, M., Nishi, S., Kumazaki, T., Hatanaka, Y., Tsuda, S., Hikichi, K. (1992). Characterization of cysteine residues of glutathione S-transferase P: evidence for steric hindrance of substrate binding by a bulky adduct to cysteine 47 . Biochem. Biophys. Res. Commun. 188:424-432.

Noguchi, N., Watanabe, A., Shi, H. (2000). Diverse functions of antioxidants. Free Radic. Res. 33:809-817.

Olson, R. E., Carpenter, P. C. (1967). The regulatory function of vitamin E. Adv. Enzyme Regul. 5:325-334.

Ong, F. B., Wan-Ngah, W. Z., Shamaan, N. A., Md-Top, A. G., Marzuki, A., Khalid, A. K. (1993). Glutathione S-transferase and gamma-glutamyl transpeptidase activities in cultured rat hepatocytes treated with tocotrienol and tocopherol. Comp. Biochem. Physiol. C 106:237-240.

Ouwerkerk-Mahadevan, S., Mulder, G. J. (1998). Inhibition of glutathione conjugation in the rat in vivo by analogues of glutathione conjugates. Chem.-Biol. Interact. 111112:163-176.

Packer, L., Weber, S. U., Rimbach, G. (2001). Molecular aspects of alpha-tocotrienol antioxidant action and cell signalling. J. Nutr. 131:369s-373s.

Paolicchi, A., Dominici, S., Pieri, L., Maellaro, E., Pompella, A. (2002). Glutathione catabolism as a signaling mechanism. Biochem. Pharmacol. 64:1027.

Parker, R. S. (1989). Dietary and biochemical aspects of vitamin E. Adv. Food Nutr. Res. 33:157-232.

Parker, R. S., Swanson, J. E. (2000). A novel 5'-carboxychroman metabolite of alphatocopherol secreted by HEPG2 cells and excreted in human urine. Biochem. Biophys. Res. Commun. 269:580-583.

Parks, E., Traber, M. G. (2000). Mechanisms of vitamin E regulation: research over the past decade and focus on the future. Antioxid. Redox Signaling 2:405-412.

Patel, J. M., Edwards, D. A. (1988). Vitamin E, membrane order, and antioxidant behavior in lung microsomes and reconstituted lipid vesicles. Toxicol. Appl. Pharmacol. 96:101-114.

Pearce, B. C., Parker, R. A., Deason, M. E., Qureshi, A., Wright, J. J. K. (1992). Hypocholesterolemic activity of synthetic and natural tocotrienols. J. Med. Chem. 35:3595-3606.

Pearce, B. C., Parker, R. A., Deason, M. E., Dischino, D. D., Gillespie, E., Qureshi, A., Volk, K., Wright, J. J. K. (1994). Inhibitors of cholesterol biosynthesis. Hypocholesterolemic and antioxidant activities of benzopyran and tetrahydronaphthalene analogues of the tocotrienols. J. Med. Chem. 37:526-541.

Pope, S. A. S., Burtin, G. E., Clayton, P. T., Madge, D. J., Muller, D. P. R. (2001). New synthesis of $( \pm)$-alpha-CMBHC and its confirmation as a metabolite of alphatocopherol (vitamin E). Bioorg. Med. Chem. 9:1337-1343.

Poppel van, G., Vogel de, N., Bladeren van, P. J., Kok, F. J. (1992). Increased cytogenetic damage in smokers deficient in glutathione S-transferase isozyme mu. Carcinogenesis $13: 303-305$. 
Prohaska, J. R. (1980). The glutathione peroxidase activity of glutathione S-transferases. Biochim. Biophys. Acta 611:87-98.

Qureshi, A., Bradlow, B. A., Brace, L., Manganello, J., Peterson, D. M., Pearce, B. C., Wright, J. J. K., Gapor, A., Elson, C. E. (1995). Response of hypercholesterolemic subjects to administration of tocotrienols. Lipids 30:1171-1177.

Qureshi, A., Pearce, B. C., Nor, R. M., Gapor, A., Peterson, D. M., Elson, C. E. (1996). Dietary alpha-tocopherol attenuates the impact of gamma-tocotrienol on hepatic 3-hydroxy-3-methylglutaryl coenzyme A reductase activity in chickens. J. Nutr. 126:389-394.

Qureshi, A. A., Sami, S. A., Salser, W. A., Khan, F. A. (2002). Dose-dependent suppression of serum cholesterol by tocotrienol-rich fraction (TRF25) of rice bran in hypercholesterolemic humans. Atherosclerosis 161:199-207.

Rahman, I., Bel, A., Mulier, B., Lawson, M. F., Harrison, D. J., Macnee, W., Smith, C. A. (1996). Transcriptional regulation of gamma-glutamylcysteine synthetase-heavy subunit by oxidants in human alveolar epithelial cells. Biochem. Biophys. Res. Commun. 229:832-837.

Reddy, C. C., Scholz, R. W., Thomas, C. E., Edward, J. M. (1982). Vitamin E dependent reduced glutathione inhibition of rat liver microsomal lipid peroxidation. Life Sci. 31:571-576.

Reed, D. J., Fariss, M. W. (1984). Glutathione depletion and susceptibility. Pharmacol. Rev. 36:25s-33s.

Ricciarelli, R., Zingg, J., Azzi, A. (2002). The 80th anniversary of vitamin E: beyond its antioxidant properties. Biol. Chem. 383:457-465.

Richman, P. G., Meister, A. (1975). Regulation of gamma-glutamyl-cysteine synthetase by nonallosteric feedback inhibition by glutathione. J. Biol. Chem. 250:1422-1426.

Rowntree, L. G., Steinberg, A., Dorrance, G. M., Ciccone, E. F. (1937). Sarcoma in rats from the ingestion of a crude wheat-germ oil made by ether extraction. Am. J. Cancer 31:359-372.

Salagovic, J., Kalina, I., Stubna, J., Habalova, V., Hrivnak, M., Valansky, L., Kohut, A., Biros, E. (1998). Genetic polymorphism of glutathione S-transferase M1 and T1 as a risk factor in lung and bladder cancers. Neoplasma 45:312-317.

Salinas, A. E., Wong, M. G. (1999). Glutathione S-transferases-a review. Curr. Med. Chem. 6:279-309.

Sato, Y., Hagiwara, K., Arai, H., Inoue, K. (1991). Purification and characterization of the alpha-tocopherol transfer protein from rat liver. Fed. Eur. Biochem. Soc. 288:41-45.

Scholz, R. W., Graham, K. S., Gumpricht, E., Reddy, C. C. (1989). Mechanism of interaction of vitamin $\mathrm{E}$ and glutathione in the protection against membrane lipid peroxidation. Ann. NY Acad. Sci. 570:514-517.

Scholz, R. W., Reddy, P. V., Wynn, M. K., Graham, K. S., Liken, A. D., Gumpricht, E., Reddy, C. C. (1997). Glutathione-dependent factors and inhibition of rat liver microsomal lipid peroxidation. Free Radic. Biol. Med. 23:815-828.

Schultz, M., Dutta, S., Tew, K. D. (1997). Inhibitors of glutathione S-transferases as therapeutic agents. Adv. Drug Deliv. Rev. 26:91-104.

Seelig, G. F., Simondsen, R. P., Meister, A. (1984). Reversible dissociation of gamma-glutamylcysteine synthetase into two subunits. J. Biol. Chem. 259:9345-9347. 
Sevanian, A., Muakkassah Kelly, S. F., Montestruque, S. (1983). The influence of phospholipase A2 and glutathione peroxidase on the elimination of membrane lipid peroxides. Arch. Biochem. Biophys. 223:441-452.

Shen, H. X., Tamai, K., Satoh, K., Hatayama, I., Tsuchida, S., Sato, K. (1991). Modulation of class Pi glutathione transferase activity by sulfhydryl group modification. Arch. Biochem. Biophys. 286:178-182.

Shi, H., Noguchi, N., Niki, E. (1999). Comparative study of antioxidative action of alphatocopheryl hydroquinone, ubiquinol, and alpha-tocopherol against lipid peroxidation. Free Radic. Biol. Med. 27:334-346.

Shuker, D. E., Atkin, W., Bingham, S. A., Leuratti, C., Singh, R. (2002). Malondialdehyde-DNA adducts in relation to diet and disease risk-a brief overview of recent results. IARC Sci. Publ. 156:475-480.

Siegel, D., Bolton, E. M., Burr, J. A., Liebler, D. C., Ross, D. (1997). The reduction of alpha-tocopherolquinone by human $\mathrm{NAD}(\mathrm{P}) \mathrm{H}$ : quinone oxidoreductase: the role of alpha-tocopherolhydroquinone as a cellular antioxidant. Mol. Pharmacol. 52:300-305.

Sies, H., Stahl, W., Sundquist, A. R. (1992). Antioxidant functions of vitamins: vitamins $\mathrm{E}$ and $\mathrm{C}$, beta-carotene, and other carotenoids. Ann. NY Acad. Sci. 669:7-20.

Sontag, T. J., Parker, R. S. (2002). Cytochrome P450 omega-hydroxylase pathway of tocopherol catabolism. Novel mechanism of regulation of vitamin E status. J. Biol. Chem. 277:25290-25296.

Stark, A. A., Zeiger, E., Pagano, D. A. (1993). Glutathione metabolism by gammaglutamyltranspeptidase leads to lipid peroxidation: characterization of the system and relevance to hepatocarcinogenesis. Carcinogenesis 14:183-189.

Stephens, N. G., Parsons, A., Schofield, P. M. (1996). Randomised controlled trial of vitamin $\mathrm{E}$ in patients with coronary disease: Cambridge Heart Antioxidant Study (CHAOS). Lancet 347:781-786.

Stocker, A., Zimmer, S., Spycher, S. E., Azzi, A. (1999). Identification of a novel cytosolic tocopherol-binding protein: structure, specificity, and tissue distribution. Int. Union Biochem. Mol. Biol. Life 48:49-55.

Stone, W. L., Dratz, E. A. (1980). Increased glutathione-S-transferase activity in antioxidant-deficient rats. Biochim. Biophys. Acta 631:503-506.

Stumpf, D. A., Sokol, R., Bettis, D., Neville, H., Ringel, S., Angelini, C., Bell, R. (1987). Friedreich's disease: V. Variant form with vitamin E deficiency and normal fat absorption. Neurology 37:68-74.

Suarna, C., Southwell-Keely, P. (1988). New oxidation products of alpha-tocopherol. Lipids 23:137-139.

Suarna, C., Craig, D. C., Cross, K. J., Southwell-Keely, P. (1988). Oxidations of vitamin E (alpha-tocopherol) and its model compound 2,2,5,7,8-pentamethyl-6-hydroxychroman. A new dimer. J. Org. Chem. 53:1281-1284.

Suarna, C., Baca, M., Southwell-Keely, P. (1992). Oxidation of the alpha-tocopherol model compound 2,2,5,7,8-pentamethyl-6-chromanol in the presence of alcohols. Lipids 27:447-453.

Suzuki, H., Sugiyama, Y. (1998). Excretion of GSSG and glutathione conjugates mediated by MRP1 and cMOAT/MRP2. Semin. Liver Dis. 18:359-376. 
Tampo, Y., Yonaha, M. (1990). Vitamin E and glutathione are required for preservation of microsomal glutathione S-transferase from oxidative stress in microsomes. Pharmacol. Toxicol. 66:259-265.

Tasinato, A., Boscoboinik, D., Bartoli, G. M., Maroni, P., Azzi, A. (1995). d-alphatocopherol inhibition of vascular smooth muscle cell proliferation occurs at physiological concentrations, correlates with protein kinase $\mathrm{C}$ inhibition, and is independent of its antioxidant properties. Proc. Natl Acad. Sci. USA 92:12190-12194.

Taylor, M. W., Nelson, V. E. (1930). Some observations on ferric chloride addition to the diet. Proc. Soc. Exp. Biol. Med. 27:764.

Theriault, A., Chao, J. T., Wang, Q., Gapor, A., Adeli, K. (1999). Tocotrienol: a review of its therapeutic potential. Clin. Biochem. 32:309-319.

Thornton, D. E., Jones, K. H., Jiang, Z., Zhang, H., Liu, G., Cornwell, D. G. (1995). Antioxidant and cytotoxic tocopheryl quinones in normal and cancer cells. Free Radic. Biol. Med. 18:963-976.

Traber, M. G., Arai, H. (1999). Molecular mechanisms of vitamin E transport. Annu. Rev. Nutr. 19:343-355.

Traber, M. G., Packer, L. (1995). Vitamin E: beyond antioxidant function. Am. J. Clin. Nutr. 62(Suppl.):1501S-1509S.

Traber, M. G., Winklhofer Roob, B. M., Roob, J. M., Khoschsorur, G., Aigner, R., Cross, C., Ramakrishnan, R., Brigelius Flohe, R. (2001). Vitamin E kinetics in smokers and nonsmokers. Free Radic. Biol. Med. 31:1368-1374.

Urata, Y., Yamamoto, H., Goto, S., Tsushima, H., Akazawa, S., Yamashita, S., Nagataki, S., Kondo, T. (1996). Long exposure to high glucose concentration impairs the responsive expression of gamma-glutamylcysteine synthetase by interleukin-1beta and tumor necrosis factor-alpha in mouse endothelial cells. J. Biol. Chem. 271:15146-15152.

Ursini, F., Maiorino, M., Valente, M., Ferri, L., Gregolin, C. (1982). Purification from pig liver of a protein which protects liposomes and biomembranes from peroxidative degradation and exhibits glutathione peroxidase activity on phosphatidylcholine hydroperoxides. Biochim. Biophys. Acta 710:197-211.

Wang, X., Quinn, P. J. (1999). Vitamin E and its function in membranes. Prog. Lipid Res. 38:309-336.

Wang, X., Quinn, P. J. (2000). The location and function of vitamin E in membranes (Review). Mol. Membr. Biol. 17:143-156.

Wardman, P. (1988). Conjugation and oxidation of glutathione via thiyl free radicals. In: Sies, H., Ketterer, B., eds. Glutathione Conjugation. Mechanisms and Biological Significance. London: Academic Press, pp. 44-72.

Wechter, W. J., Kantoci, D., Murray, E. D. J., D’Amico, D., Jung, M. E., Wang, W. H. (1996). A new endogenous natriuretic factor: LLU-alpha. Proc. Natl Acad. Sci. USA 93:6002-6007.

Weinberg, R. B., VanderWerken, B. S., Anderson, R. A., Stegner, J. E., Thomas, M. J. (2001). Pro-oxidant effect of vitamin $\mathrm{E}$ in cigarette smokers consuming a high polyunsaturated fat diet. Arterioscler. Thromb. Vasc. Biol. 21:1029-1033.

Whitfield, J. B. (2001). Gamma glutamyl transferase. Crit. Rev. Clin. Lab. Sci. $38: 263-355$. 
Wijesundara, M. B. J., Berger, S. (1994). The redox pair vitamin E and vitamin C, a 13CNMR study. Liebigs Ann. Chem.1239-1241.

Wild, A. C., Mulcahy, R. T. (2000). Regulation of gamma-glutamylcysteine synthetase subunit gene expression: insights into transcriptional control of antioxidant defenses. Free Radic. Res. 32:281-301.

Woods, J. S., Ellis, M. E. (1995). Up-regulation of glutathione synthesis in rat kidney by methyl mercury. Relationship to mercury-induced oxidative stress. Biochem. Pharmacol. 50:1719-1724.

Yusuf, S. (2000). Vitamin E supplementation and cardiovascular events in high-risk patients. The Heart Outcomes Prevention Study Investigators. N. Engl. J. Med. 342:154-160.

Zimmer, S., Stocker, A., Sarbolouki, M. N., Spycher, S. E., Sassoon, J., Azzi, A. (2000). A novel human tocopherol-associated protein: cloning, in vitro expression, and characterization. J. Biol. Chem. 275:25672-25680. 